\title{
Redefinition of the identity and phylogenetic position of Tityus trivittatus Kraepelin 1898, and description of Tityus carrilloi n. sp. (Scorpiones; Buthidae), the most medically important scorpion of southern South America
}

\author{
Andrés Alejandro OJANGUREN AFFILASTRO ${ }^{1 *}$; John KOCHALKA ${ }^{2}$; David \\ GUERRERO-ORELLANA²; Bolívar GARCETE-BARRETT²; Adolfo Rafael de ROODT³; \\ Adolfo BORGES ${ }^{4} \&$ F. Sara CECCARELLI ${ }^{5}$
}

\begin{abstract}
${ }^{1 *}$ Museo Argentino de Ciencias Naturales "Bernardino Rivadavia”. Av. Ángel Gallardo 470. Buenos Aires Argentina. andres.ojanguren@gmail.com \& ojanguren@macn.gov.ar. Corresponding author. ${ }^{2}$ Museo Nacional de Historia Natural del Paraguay - Ministerio del Ambiente y Desarrollo Sostenible. San Lorenzo, Paraguay. ${ }^{3}$ Área Investigación y Desarrollo-Venenos/Serpentario-Aracnario, Instituto Nacional de Producción de Biológicos ANLIS "Dr. Carlos G. Malbrán”, Ministerio de Salud. Argentina. ${ }^{4}$ Centro para el Desarrollo de la Investigación Científica (CEDIC), Manduvirá 635 c/15 de agosto. Asunción, Paraguay. ${ }^{5}$ Departamento de Biología de la Conservación, CONACYT-Centro de Investigación Científica y de Educación Superior de Ensenada (CICESE), Carretera Ensenada-Tijuana No. 3918, Zona Playitas, C.P. 22860 Baja California, México.
\end{abstract}

\begin{abstract}
Tityus trivittatus is considered the most medically important scorpion species of southern South America. In this contribution we redefine its taxonomy, redescribe the species and separate the southern populations as a new species, Tityus carrilloi $\mathrm{n}$. sp. As a consequence of this description, the most medically important species of the region turns out to be the new species herein described. We also clearly establish the phylogenetic position of both species through a dated molecular phylogenetic analysis based on four genes. Finally, we discuss the differences of the venom between the two species, and the epidemiologic implications of our results on the scorpionism problem in the region.
\end{abstract}

Keywords: Tityus, taxonomy, dated phylogeny, scorpionism, SouthAmerica.

Resumen: Redefinición de la identidad y posición filogenética de Tityus trivittatus Kraepelin 1898, y descripción de Tityus carrilloi $\mathrm{n}$. sp. (Scorpiones; Buthidae), la especie de mayor importancia médica del sur de Sudamérica. Tityus trivittatus es considerada la especie de escorpión de mayor importancia médica en el sur de Sudamérica. En este trabajo redefinimos su taxonomía, redescribimos esta especie y separamos las poblaciones meridionales como una nueva especie Tityus carrilloi n. sp. Como consecuencia de esta descripción, la especie de mayor importancia médica de la región es la especie que describimos aquí. Establecemos además claramente la posición filogenética de ambas especies a través de una filogenia molecular datada basada en cuatro genes. Finalmente discutimos las diferencias del veneno entre ambas especies y las implicaciones epidemiológicas de nuestros resultados sobre el problema del escorpionismo en la región.

Palabras clave: Tityus, taxonomía, filogenia datada, escorpionismo, Sudamérica.

\section{INTRODUCTION}

The scorpion genus Tityus includes all medically important species of southern South America, being responsible for several deaths every year in this region (de Roodt et al., 2003, 2009, 2010, 2019; de Roodt, 2014; Ministerio de Salud, 2011; Docampo \& Fernández, 2011; Blanco et al., 2016). Some of these species of medical importance are parthenogenetic and synanthropic, which makes them extremely efficient invaders of human settlements (Toscano-Gadea, 2004; Lourenço, 2015). Thanks to this, many of them have largely expanded their distribution in the last years occupying most anthropized areas, resulting in an increasingly complex scenario for the scorpionism problem in South America (Blanco et al., 2016; Ojanguren-Affilastro et al., 2019).

One of the first steps to develop health policies to deal with scorpionism should be to clearly 
establish the identity of the species of medical importance, so that the control strategies and antivenom production can be clearly focused to the correct target. This task however, has not been simple in South America, mostly due to the different criteria of different local specialists in species recognition, and the poor exchange of information between specialists of neighboring countries dealing with similar problems.

Due to its medical importance, Tityus is one of the most studied scorpion genera, but despite this, its taxonomy is far from being solved and has been revealed as one of the most complex genus in the order (Lourenço, 2006). Up to now, Tityus trivittatus Kraepelin, 1898 is considered the most medically important scorpion species south of the $24^{\circ}$ parallel in South America, with a distributional range occupying eastern Paraguay, southern Brazil, part of Uruguay, and especially, most of central and northern Argentina, including all major cities of this country (Borges \& Rojas de Arias, 2019; Ojanguren-Affilastro et $a l ., 2019)$. Due to this, most control plans, and antivenom production for scorpions in Argentina were focused on this species (de Roodt, 2014; de Roodt et al., 2003, 2010; Ministerio de Salud, 2011).

In the framework of a collaborative research project between specialists of five different institutions of Argentina, Paraguay and Mexico, we have been able to revise a large amount of specimens currently considered as T. trivittatus, from all its distributional range, which led us to clearly establish the identity of this species. As a result, we could determine that $T$. trivittatus is restricted to the eastern part of Paraguay and a small part of Southwestern Brazil, whereas in Argentina and Uruguay the specimens currently considered as $T$. trivittatus, actually belong to a different undescribed species. Therefore, the most medically important species of southern South America, turns out not to be T. trivittatus but a new species that is described herein as Tityus carrilloi $\mathrm{n}$. sp. In this contribution we also redescribe $T$. trivittatus and provide distribution maps of both species. We also provide a dated molecular phylogeny of the southernmost species of Tityus based on four genes, in which we included both studied species; therefore we provide information on their phylogenetic position and relationships within the genus.

Finally, we provide a brief discussion about the different characteristics of their venoms and toxicity. Most of which has been described during the last years about the venom, antivenom, tox- icity and lethality of T. trivittatus actually corresponds to T. carrilloi $\mathrm{n}$. sp. because most studies were carried out on Argentinean populations of this species (Coronas et al., 2003, 2015; de Roodt et al., 2001, 2010, 2019). Therefore, the taxonomic changes herein presented, change the scenery of what is known about the scorpionism problem in the region. Due to the great medical importance of both herein studied species, we consider it necessary to take the chance to provide an updated overview of the venom and toxicity of both species, considering for the first time each species separately.

\section{On the identity of T. trivittatus}

Tityus trivittatus was originally described based on two $\sigma^{\prime \prime}$ syntypes from San Salvador in Paraguay, by Kraepelin (1898). This locality does not correspond to the actual Paraguayan locality of San Salvador in the Department of Guairá, in southern Paraguay, because it was founded in 1951 and it didn't exist in the nineteenth century. The type locality corresponds to an old village, currently abandoned, which was placed approximately at $22^{\circ} 49^{\prime} 00^{\prime \prime} \mathrm{S} 57^{\circ} 47^{\prime} 00^{\prime \prime} \mathrm{W}$, in the northern Department of Concepción, as stated by Maury (1970) and later by Lourenço (1980).

Shortly after the description of $T$. trivittatus, Borelli (1899) mistook it for T. carrilloi n. sp., and mentioned its presence in Argentina for the first time, in the province of Chaco. After that, several authors confused both species and repeatedly mentioned the presence of $T$. trivittatus in Argentina (see synonymic list), also extending its known distribution to other provinces.

The most influential paper of South American scorpiology of the twentieth century was the large monograph on South American scorpions by Mello-Leitão (1945); in that contribution the author included a detailed drawing of $T$. trivittatus, taken from his previous paper on the Argentinean scorpiofauna (MelloLeitão, 1934), this figure clearly corresponds to an Argentinean specimen of T. carrilloi n. sp.. Additionally, he mentioned the presence of $T$. trivittatus in the city of Buenos Aires, confusing both species. After that, the presence of T. trivittatus in Argentina was assumed as correct by all posterior authors.

Maury (1970) was the first specialist who attempted to re-describe $T$. trivittatus with modern standards. He followed the widely accepted species concept of Mello-Leitão (1934, 1945), and based his work mostly in Argentinean specimens of T. carrilloi n. sp., therefore he also confused 
both species. Shortly after, Maury (1974) studied the types of Tityus confluens and Tityus trivittatus, and separated both as valid species; in this period he also left an unpublished redescription and drawings of the types of T. trivittatus (Maury unpublished data at Museo Argentino de Ciencias Naturales "Bernardino Rivadavia" (MACN)). Lourenço (1980) also studied the syntypes of $T$. trivittatus, provided a detailed drawing of the pigment pattern of one of them, and briefly re-described the species; however this description partially follows the above mentioned Maury's paper of 1970, therefore also confusing both species. More recently Maury (1997) published an updated contribution on T. trivittatus, after revising a larger amount of specimens, including the types of this species (as mentioned before); but still considering Argentinean specimens of T. carrilloi n. sp. as T. trivittatus.

We have studied the scorpion collection of the Inventario Biológico Nacional de Paraguay (IBNP), which includes a large collection of $T$. trivittatus from all the country. Additionally, we have surveyed several localities of Paraguay, including some close to the type locality of this species. We have also studied a large amount of specimens from the MACN, assigned to T. trivittatus from Argentina, Brazil, Paraguay and Uruguay, and we have widely collected in northeastern Argentinean provinces in the border with Paraguay and Brazil, as well as in the south western Brazilian states. Due to all this, we have been able to study a large amount of specimens from all its distributional range, and found conspicuous and consistent differences in pigment pattern, external morphology, and hemispermatopohore morphology, between Paraguayan and Argentinean specimens, which clearly separate them as different species. We have also sequenced four molecular markers of specimens both, from Argentina and Paraguay, and performed a molecular phylogeny, which clearly placed Paraguayan specimens of T. trivittatus as a different species from Argentinean specimens of T. carrilloi n. sp. which indeed is most closely related to Tityus confluens Borelli, 1899 (Fig. 1).

We studied the unpublished description and drawings of the syntypes of $T$. trivittatus by E. Maury, and they clearly correspond to Paraguayan specimens, and not to Argentinean specimens. The pigment pattern of the figure of one syntype of Tityus trivittatus published by Lourenço (1980) also undoubtedly corresponds to the pigment pattern of Paraguayan specimens. We have studied high quality photos of the best preserved syntype of this species kindly sent by Nadine Dupérré, curator of the Zoologischer Museum Hamburg (ZMH), and we could clearly observe the most important external diagnostic characters of the Paraguayan specimens, that separate them from the Argentinean specimens.

Due to all this we concluded that the Paraguayan specimens are conspecific with the syntypes of T. trivittatus, and that Argentinean specimens correspond to the species herein described as T. carrilloi $\mathrm{n}$. sp.

\section{MATERIALS AND METHODS}

\section{Taxon Sampling}

In this contribution we will accept the concept of species groups and complexes used for the genus Tityus (Lourenço, 1979, 1980, 1981, 1982; Lourenço \& Maury, 1985), but we will consider these subdivisions as synonyms, and in general refer to them as "complexes". We will accept the sub-generic division of genus Tityus of Lourenço (2006). We will follow the generic group division of family Buthidae suggested by Fet et al. (2005). A priori we will consider all subgenera and genera as monophyletic.

Most studied specimens belong to two different collections: Museo Argentino de Ciencias Naturales Arachnological collection (MACN-Ar, Martín Ramírez), Buenos Aires, Argentina; and the Inventario Biológico Nacional de Paraguay (IBNP, John Kochalka), Asunción, Paraguay. Since both herein studied species are synanthropic, most studied specimens for taxonomic studies were spontaneously deposited for identification by people in the above-mentioned institutions. Additionally, some specimens were manually collected by the authors at night using UV lamps, or during the day under stones, or logs. Licenses for legal collection were obtained in each case. For a list of the studied specimens of T. carrilloi $\mathrm{n}$. sp. see Maury (1970, 1997); for a list of the studied specimens of T. trivittatus see Maury $(1970,1997)$ and Guerrero \& Kochalka (2015).

Point locality records were georeferenced in the field with portable Global Positioning System devices (Garmin ${ }^{\circledR}$ GPS II Plus, Etrex, Etrex Vista and Etrex Vista C) or retroactively using the GeoNet Names Server (https://geonames. nga.mil/gns/html/). A distribution map was generated using the web site www.simplemappr.net.

Most sequenced terminals used in this analysis correspond to a previous contribution of two of the authors (Ojanguren-Affilastro et al., 
2017a) with a phylogenetic study of southernmost American Buthids. Additionally, we included sequences of two specimens of T. trivittatus from Asunción, Paraguay. We have included all known species of Tityus from southern part of South America: Tityus argentinus Borelli, 1899, Tityus bahiensis (Perty, 1833), Tityus carrilloi n. sp., T. confluens, Tityus curupi OjangurenAffilastro, Adilardi, Cajade, Ramírez, Ceccarelli \& Mola, 2017, Tityus paraguayensis Kraepelin, 1895, Tityus serrulatus Lutz \& Mello, 1922, Tityus trivittatus Kraepelin, 1898, and Tityus uruguayensis Borelli, 1901. We also included some data from related species available from nearby areas. From the subgenus Tityus we included Tityus carvalhoi Mello-Leitão, 1945, from southern Brazilian Cerrado. From the subgenus Archaeotityus we included Tityus mattogrossensis Borelli, 1901 from Southern Brazilian Cerrado, Tityus bastosi Lourenço, 1984 from tropical forests of Ecuador, and the type species of the subgenus Tityus clathratus Koch, 1845 from northern South America. From the bolivianus group of the subgenus Tityus we included two Andean Bolivian species Tityus soratensis Kraepelin, 1912, and Tityus andinus Kraepelin, 1911. We also included some representatives belonging to subgenus Atreus from northern South America: Tityus nematochirus Mello-Leitão, 1940, Tityus pachyurus Pocock, 1897, Tityus perijanensis González-Sponga, 1994, and Tityus discrepans (Karsch, 1879). In total, we used 20 individuals belonging to 19 species of Tityus.

As outgroups we have included other three Buthids: Zabius birabeni Mello-Leitão, 1938, from central Argentina, belonging to the Tityus group; Grosphus flavopiceus Kraepelin, 1900, from Madagascar, belonging to the Uroplectes group and Ananteris balzanii Thorell, 1891, from northern Argentina, belonging to the Ananteris group.

Sequences are deposited in GenBank (for accession numbers, see Appendix S1).

\section{Taxonomy}

Descriptive terminology follows OjangurenAffilastro (2005), Maury (1970) and OjangurenAffilastro et al. (2017b), for hemispermatophores. Vachon (1974) for trichobothria. Ochoa et al. (2010) for metasomal carinae, abbreviated as follows: DL: dorsolateral; LIM: lateral inframedian; LSM: lateral supramedian; LM: lateral median; VSM: ventral submedian; VL: ventrolateral; VM: ventromedian. Prendini (2000) for pedipalp carinae, abbreviated as follows: DI: dorsal internal; DE: dorsal external; VI: ventral internal; SD: sub digital; VE: ventral external; D: digital; E: external; IM: internomedian; EM: externomedian; V: ventral; VM: ventral median; DM: dorsal marginal; DS: dorsal secondary.

Measurements were taken using an ocular micrometer and are expressed in $\mathrm{mm}$. Digital images of pigmentation pattern and habitus were taken under visible light, whereas images of external morphology were taken under UV light; we used a digital camera (Leica DFC290 or Nikon DS-Fi1) attached to a stereomicroscope (Leica M165C or Nikon SMZ1500), and the focal planes fused with Helicon Focus 3.10.3 (http:// helicon.com.usa/heliconfocus/).

\section{DNA Sequencing, sequence alignment and phylogenetic analyses}

As mentioned previously, most sequences used in this analysis correspond to a previous contribution of two of the authors (OjangurenAffilastro et al., 2017a). Additionally, we included sequences of two specimens of T. trivittatus from Asunción, Paraguay, one from Borges et al. (2020a), and a specimen deposited in MACN-Ar (41603). DNA extraction, PCR amplification, and sequencing of the four gene fragments (COI, 16S rDNA, 28S rDNA and H3a) for an additional Tityus trivittatus specimen was carried out following the procedures described in OjangurenAffilastro et al. (2017a). The amplified fragments were sent for sequencing at Macrogen Inc., Korea. The new sequences were combined with sequences from the aforementioned taxa in a multiple alignment, substitution models selected, and Bayesian phylogenetic analyses run by Markov Chain Monte Carlo (MCMC) simulation in MrBayes v 3.2.6 (Ronquist et al., 2012) and BEAST v. 1.10.4 (Drummond et al., 2012), as in Ojanguren-Affilastro et al. (2017a). For the node age estimates in BEAST, a rate of 0.0086 substitutions/myr was applied as the mean for a normal prior (with 0.001 standard deviation) of the uncorrelated lognormal clock rate for the COI fragment. These values were obtained from the phylogenetic analyses with calibrated nodes from Ojanguren-Affilastro et al. (2017a). Nodal support of the Bayesian phylogenies was assessed based on posterior probabilities.

\section{RESULTS}

\section{Taxonomy}


Scorpiones C. L. Koch, 1850

Buthoidea Simon, 1879

Buthidae C. L. Koch, 1837

Tityus C. L. Koch, 1836

Tityus carrilloi n. sp. Ojanguren-Affilastro (Figs. 1-8)

Zoobank registration: http://zoobank.org/ urn:lsid:zoobank.org:act:8C153A21-BD52-48A09D50-6D4439B8E7D0

Type material: Holotype ơ: Argentina, Chaco province, Paraje La Armonia (29 09'14.28"S; 56 51'50.14”W), 11/X/2013, L. Damer coll., (MACN-Ar 41596). Paratypes: Argentina, Corrientes province: 3 \& Corrientes city (290'ㄴ.85'S; 56655'05.81'W), 23/IX/1991, Varisco Coll. (MACN-Ar 41599); 1 o' Bella Vista, $\quad\left(2^{\circ} 33^{\prime} 47,31^{\prime \prime} \mathrm{S} ; \quad 59^{\circ} 02^{\prime} 32,70^{\prime \prime} \mathrm{W}\right), \quad 10 /$ $\mathrm{XI} / 1980$, J. Williams coll. (MACN-Ar 41600). Chaco province: $10^{\text {* }}$ Samuhu, (27 $31^{\prime} 12,36^{\prime}$ 'S; $60^{\circ} 23^{\prime} 56,95^{\prime}$ 'W), II/1947, M. Biraben coll. (MACN-Ar 41601). Entre Ríos province: 3 \%, Paraná city (314ㄴ $45,27^{\prime \prime} S$; $\left.60^{\circ} 30^{\prime} 57,77^{\prime \prime} \mathrm{W}\right)$, XI/1968, Paggi coll. (MACN-Ar 41602).

References: Tityus trivittatus: Borelli, 1899: 4-5 (part); Borelli, 1901: 5-6 (part); Mello-Leitão 1931: 128,129, 144 (part); Mello-Leitão, 1932: 17, 18, 29 (part); Mello-Leitão, 1934: 22, 23 (part); Mello-Leitão, 1938: 93-95 (part); MelloLeitão, 1939a: 62, 64, 73 (part); Mello-Leitão, 1939b: 611(part); Mello-Leitão, 1945: 300, 364367 (part); Ábalos, 1959: 592; Ábalos, 1963: 113; Bucherl, 1964: 59 (part); Bücherl, 1969: 768 (part); Maury, 1970: 405-421(part); Bücherl, 1971: 327, 330, 332 (part); Maury, 1974: 89, 91 (part); Lourenço, 1980: 793-840 (part); Maury, 1986: 4, 10; Acosta, 1991: 11; Kovarik, 1992: 184; Peretti: 1994: 9-21; Acosta, 1995: 57; Acosta \& Rosso de Ferradás, 1996: 84; Lourenço, 1997: 596 (part); Maury, 1997: 1-21 (part); Acosta \& Maury, 1998: 559; de Roodt et al,. 2001: 99-109; Lourenço, 2001: 160, 161, 166 (part); Salomon \& de Roodt, 2001: 391-396; Murúa et al., 2002: 75-78; de Roodt et al., 2003: 971-977; ToscanoGadea, 2004: 866-869 (part); OjangurenAffilastro, 2005: 92-94 (part); FernándezCampón \& Lagos-Silnik, 2009: 219-221; de Roodt et al., 2010: 307-319; Docampo \& Fernández, 2011: 16-18; Seiter, 2012: 117; Toscano-Gadea, 2012: 83, 86, 87 (part); Adilardi et al., 2014: 8188 (part); Coronas et al., 2015: 11-16; de Roodt, 2014: 1434-1452; de Roodt et al., 2014: 5-13; de
Roodt, 2015: 55-71; Adilardi et al., 2015: 394; Guerrero \& Kochalka, 2015: 62, 63, 64 (part); Blanco et al., 2016: 77-83; Carvalho et al., 2017: 1-6 (part.); de Roodt et al., 2017: 1-24; Faúndez \& Albornoz, 2017: 165-166 (part.); OjangurenAffilastro et al., 2017a: 44, 45 (part.); OjangurenAffilastro et al., 2017b: 6, 11, 13 (part.); Ojeda \& Neder, 2017: 12-22; Seiter \& Stockmann, 2017: 155-158, 160-163 (part); Fernández et al., 2018: 12-18; Martínez et al., 2018: 62-72; Borges \& Rojas de Arias, 2019: 27-35 (part); de Roodt et al., 2019: 5-13; López et al., 2019: 51-54; OjangurenAffilastro et al., 2019: 101, 102, 104, 105 (part.); Borges et al., 2020a: 2, 10, 15, 18, 21 (part).

Tityus trivittatus trivittatus: Mello-Leitão, 1945: 310 (part); Ringuelet, 1953: 278; Maury, 1970: 406-414 (part); 1974: 85, 89, 91 (part.); Lourenço, 1979: 37-45 (part); Maury, 1979: 705 (part); Lourenço, 1980: 797, 798, 839 (part.).

Etymology. This species is named after Ramón Carrillo, the first minister of health of Argentina as homage to his work for the Argentine public health. Ramón Carrillo was a neurobiologist and neurosurgeon, and was responsible for many advances in Argentine public health during his work as minister. He died exiled and in poverty in 1956 in Brazil at the age of 50.

Diagnosis and comparisons. A medium sized species of Tityus belonging to the trivittatus complex and to the nominotypic subgenus.

Tityus carrilloi $\mathrm{n}$. sp. is most closely related to T. confluens. Both species can be easily separated by their pigmentation pattern. In T. carrilloi $\mathrm{n}$. sp. tergites I-VI bear three pigment spots two lateral and one median (Fig. 4C), whereas in $T$. confluens tergites I-VI are completely covered by pigment.

Tityus carrilloi n. sp. is externally more similar to T. trivittatus with which it has been confused up to now; both species can be easily separated by their pigmentation pattern; both species bear three pigment spots on tergites IVI forming three dark dorsal stripes, two lateral and one median, however in T. carrilloi $\mathrm{n}$. sp. the dark areas are comparatively narrower than the unpigmented areas; the median spot in is subtriangular, with one apex in the anterior margin, and one side on the posterior margin, being the whole spot uniformly and densely pigmented (Fig. 4C), whereas in T. trivittatus the median spot is almost squared, with an unpigmented median area, which in some cases is so large that 


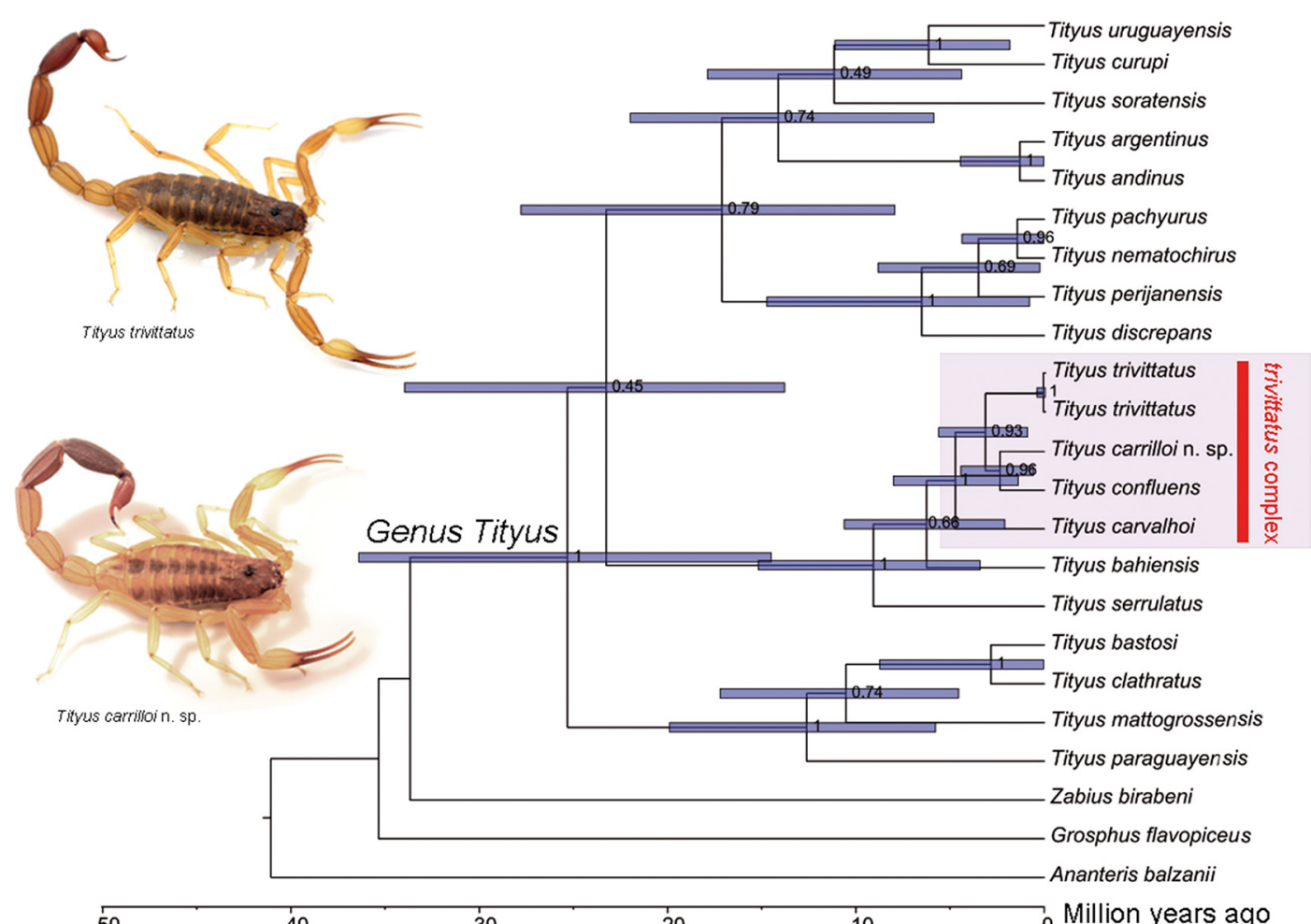

Fig. 1. Phylogenetic tree for the southernmost American species of Tityus with node age estimates inferred by BEAST. 95\% Highest Posterior Density of node heights are shown by blue bars. Major clades are indicated on left of the tree. Time scale is indicated below the tree.

it divides the square into two separated spots; the lateral spots are C shaped in both species, with an internal unpigmented area, being these pigmented spots narrower in T. carrilloi $\mathrm{n}$. sp. and with a less developed internal unpigmented area (Fig. 4F). Most specimens of T. carrilloi $\mathrm{n}$. sp. bear a median dorsal spot in pedipalp patella (Figs. 3A, C), as well as a ventromedian stripe in metasomal segments which are always absent in T. trivittatus (Figs. 9A, C).

There are other conspicuous somatical differences. The dorsal median carina of tergites I-VI is complete in T. carrilloi n. sp., ranging from the posterior margin to the transversal carina of the pretergite (Fig. 6C), whereas in T. trivittatus it is incomplete, usually occupying only the posterior half of the segment, barely exceeding its median double area (Fig. 6F). The LIM carina of metasomal segment II occupies the entire length of the segment in T. carrilloi n. sp. (Fig. 7E), whereas in T. trivittatus it is absent or reduced to the posterior third of the segment (Fig. 7F).

Additionally, there are less conspicuous differences between species; T. carrilloi $\mathrm{n}$. sp. tends to be less granular and slightly smaller than $T$. trivittatus. The pedipalp chela of $T$. carrilloi $\mathrm{n}$. sp. males (Fig. 5B) is higher than that of T. trivittatus (Fig. 10B), but presents smaller internal lobe on the movable finger. Metasomal segment $\mathrm{V}$ of T. carrilloi $\mathrm{n}$. sp. is higher and wider than in T. trivittatus, being this difference particularly conspicuous in males (Figs. 7A, C). Spiracles are narrower or more compressed anteroposteriorly in T. carrilloi n. sp. than in T. trivittatus (Figs. $6 \mathrm{~A}, \mathrm{~B}, \mathrm{D}, \mathrm{E})$. Basal lobe of the hemispermatophore is hook shaped in both species, but it has a wider internal concavity in T. carrilloi n. sp. Both internal and external lobes are more conspicuous in T. carrilloi n. sp. than in T. trivittatus (Figs. 8C, 11C).

Description. Based on the holotype $0^{x}$, and paratypes (MACN). Total length: 53.70-62.50 $\mathrm{mm}(n=4$; mean=56.25) in o'; 49.90-65.00 mm $(n=10$; mean $=55.20)$ in 9 . Colour: Base colour yellowish, with dark brown pattern in chelicerae, chelae, legs, carapace, tergites and metasoma (Figs. 3A, B, C, D). Chelicerae: light yellow with a dense reticulate pattern in manus and fingers, which can be faint in some specimens. Carapace: 


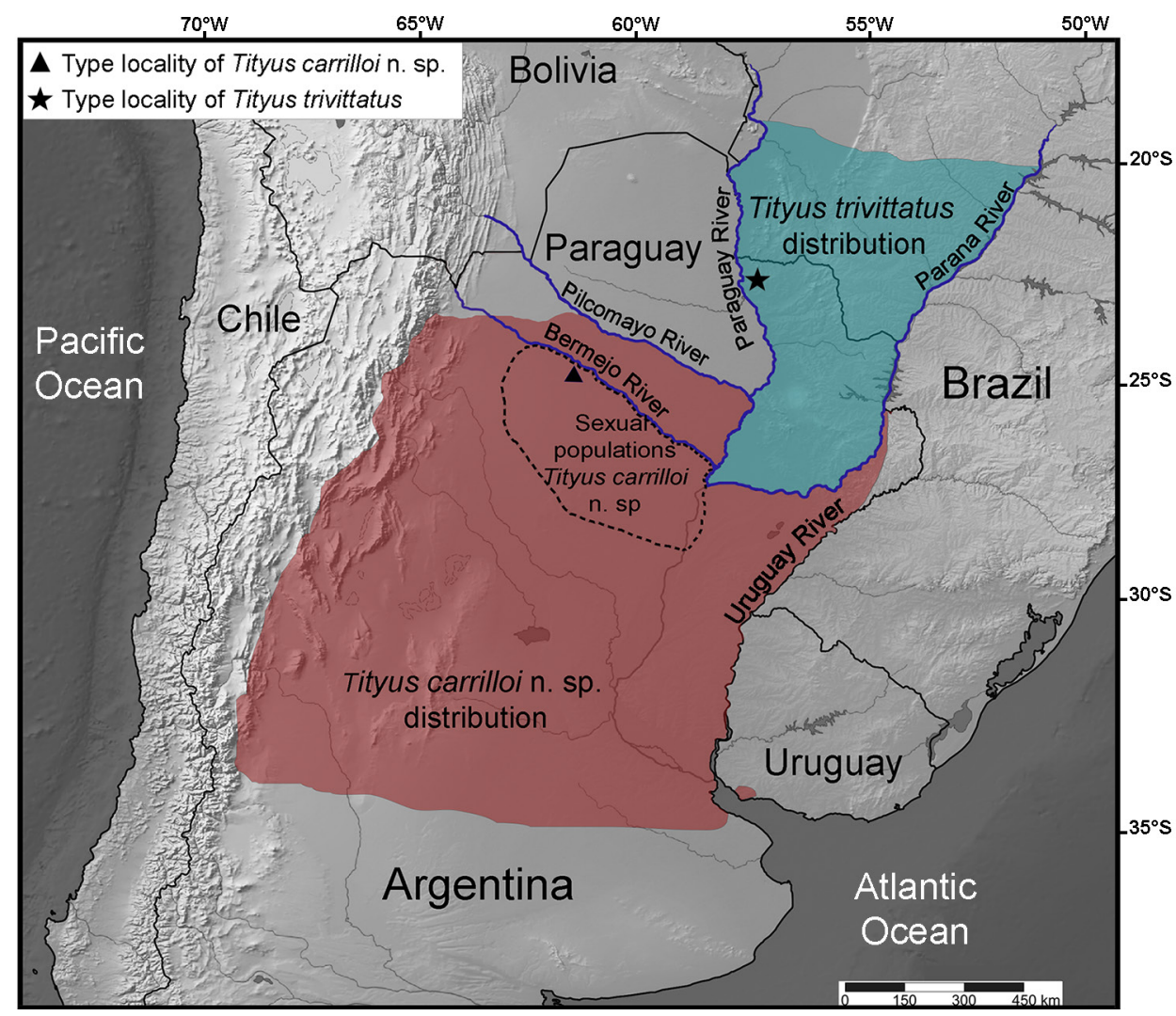

Fig. 2. Map of southern South America, with known distribution of Tityus carrilloi n. sp. (shaded red) and Tityus trivittatus (shaded blue). Type locality of each species is marked by a black triangle and a black star respectively. Larger rivers of the region acting as a barrier for these species are also marked.

with black areas around ocular tubercle and lateral eyes; densely pigmented in the anterior and lateral margins, with a unpigmented area $\mathrm{Y}$ shaped from the posterior margin to the ocular tubercle. Tergites I-VI (Fig. 4C) each with three dark spots extending the entire length of the segment, two laterals, and a median dark spot; these spots are not connected to each other, leaving two wide unpigmented stripes, the median spot is subtriangular, with its anterior margin being acute and its posterior margin being the posterior margin of the triangle; lateral sports are C shaped. Tergite VII only with a median elongated subriangular stripe, with a wider anterior margin and a thin posterior margin. Sternites, sternum, genital opercula and pectines unpigmented. Metasomal segments I-III general yellowish colour, dorsally with a thin median stripe along the dorsal median furrow, this stripe can be absent or faint in some specimens; lateral margins unpigmented; ventral margin with a median stripe occupying the area between VSM carinae, this stripe is usually well marked in juveniles, but in adults it is faint or irregularly marked in most specimens, being absent in some specimens. Metasomal segment IV general colour reddish, dorsally unpigmented or with an anterior median faint pigment triangle occupying the posterior two thirds of the segment, ventrally as segments I-III. Metasomal segment V general colour reddish-brown, darker in males, ventrally some specimens with a thin dark stripe along the VM carina, the rest unpigmented. Telson, vesicle general colour reddish, aculeus dark brown. Pedipalps: femur unpigmented or with a small postero-dorsal spot in the articulation with patella; patella of most specimens with a brown spot covering most of the anterior, dorsal and posterior margins, ventrally unpigmented; this spot can be absent in some specimens; chella manus unpigmented; fingers dark reddish brown. Legs: usually unpigmented, some specimens with a faint brownish pattern in the external margins of femur, patella, tibia and basitarsus.

Carapace. Anterior margin with a conspicuous broad median notch that divides the anterior 
margin into two lobes. Surface densely granular. Anteromedian longitudinal sulcus, interocular sulcus; posteromedian longitudinal and lateral sulci present and conspicuous. Median ocular tubercle well developed, and clearly protruding above carapace in lateral profile; median ocelli well developed, approximately one diameter apart. Three small lateral ocelli on each side of carapace. Anterior median carinae, median ocular carinae, lateral carinae, and posterior carinae all granular and well developed (Figs. 4A, B).

Chelicerae. Tegument granular, especially near the distal margin, more so in males. Dentition typical for the genus. Teeth well developed.

Pedipalps. Femur, intercarinal surfaces densely granular except for the ventral surface which is barely granular, with smooth parts; DE, DI, VE and VI carinae granular and well developed, extending the entire length of the segment; internal margin with an interno-median (IM) carina extending the entire length of the segment. Patella intercarinal surfaces sparsely granular DI, DM, DE, IM VI, VE and EM carinae granular, extending the entire length of the segment, proximal granules of IM carinae are two or three times more developed than the rest. Chela manus slender, being more robust in $\sigma^{x}$, length/height ratio, o: 4.57-5.26 ( $\mathrm{N}=10$; mean=4.9), ơ: 3.73-4.15 $(\mathrm{N}=4$; mean $=3.99)$; length/width ratio, $\%: 4.79$ $5.71(\mathrm{~N}=10$; mean=5.14), or: 3.86-4.40 $(\mathrm{N}=4$; mean $=4.16$ ), DI, DE, DS, D, SD, E, VE, VI, and IM carinae granular and well developed, being the VI carina less developed in females (Figs. $5 \mathrm{~A}-\mathrm{H}$ ); fixed and movable fingers thin, elongated and slightly curved internally; movable finger with 16 , or 17, sub-parallel barely transversal denticle rows, being the basal row longitudinal basally and sometimes formed by the fusion of two denticle rows (Fig. 5A); fixed finger with 14 or 15 sub-parallel denticle rows, being the basal row longitudinal and always formed by the fusion of two or three denticles rows (Fig. 5C); each of these denticles rows presents and apical enlarged tooth and two basal enlarged teeth, which are two or three times bigger than the rest of the denticles; the apical enlarged tooth presents a hyaline and a chitinized seta at its base; the most apical of the basal enlarged denticles presents a single hyaline seta at its base, and the most basal presents a chitinized setae in its base; at the apical margin of each finger there is an apical tooth with two lamellar, and two wide setae surrounding its basal margin. Movable finger with a basal lobe poorly developed in $\sigma^{*}$ (Figs. 5B, D), absent or inconspicuous in $\$$ (Figs. 5F, H); fixed finger straight in $\$$, with a small shallow notch facing the basal lobe in or. Trichobothrial pattern orthobothriotaxic type A; femur with 11 trichobothria, $\alpha$ configuration and trichobothria $d_{2}$ placed on the internal surface; patella with 13 trichobothria; chela with 15 trichobothria, being esb petit.

Legs. Intercarinal surfaces finely granular. Carinae granular, extending the entire length of the segment. Basitarsi each with two well developed, equal-length pedal spurs; the external one presents an external, very well developed, macroseta. Telotarsi short, ventrally with abundant chitinized setae, and some VL hyaline setae with following counts, on legs I to III: $4 / 3$, IV: 5/4. Pseudoniquium elongated. Ungues well developed, equal in length and curved.

Sternum. Sub-triangular.

Genital opercula. Medium sized. Sclerites with a general subtriangular shape but with a curved anterior margin, in $\%$ the posterior margin of the sclerites is also curved whereas in $0^{\prime}$ it is almost straight and perpendicular to the axis of the body.

Pectines. With a single row of median lamellae; first median lamella nearly similar in size in $\sigma^{\top}$ and $\$$ (Figs. 6A, B). Fulcra present, small and subcircular. Pectinal teeth medium sized; tooth count: $20-22$ in $\sigma^{7}(n=4$; median $=21), 19-21$ in ᄋ $(n=10$; median $=21)$.

Tergites. Pretergites with fine granulation, separated from the rest of the tergite by a well developed anterior transversal carina. Tergites I-VI, surfaces granular being more coarse so in the posterior half of the segment, with a barely visible incomplete transversal carinae separating anterior and posterior halves of each tergite; with a dorsal-median longitudinal carinae extending from the posterior margin to the base of the pretergite (Fig. 6C); the dorsal median carina is formed posteriorly and anteriorly by a single row of granules that becomes double in its median part; with two very small dorso-submedian carinae barely protruding from the pretergite transversal carina, being more conspicuous in the posterior segments; posterior margin more densely granular, almost forming a posterior transversal carina. Tergite VII surfaces granular, dorsal-median carina extending the anterior two thirds of the segment, formed by a double row of granules in its anterior half, fusing in a single row in the second half; with four longitudinal dorso-submedian carinae extending the entire length of the segment, fusing anteriorly to each other in a subcircular transversal carina, 

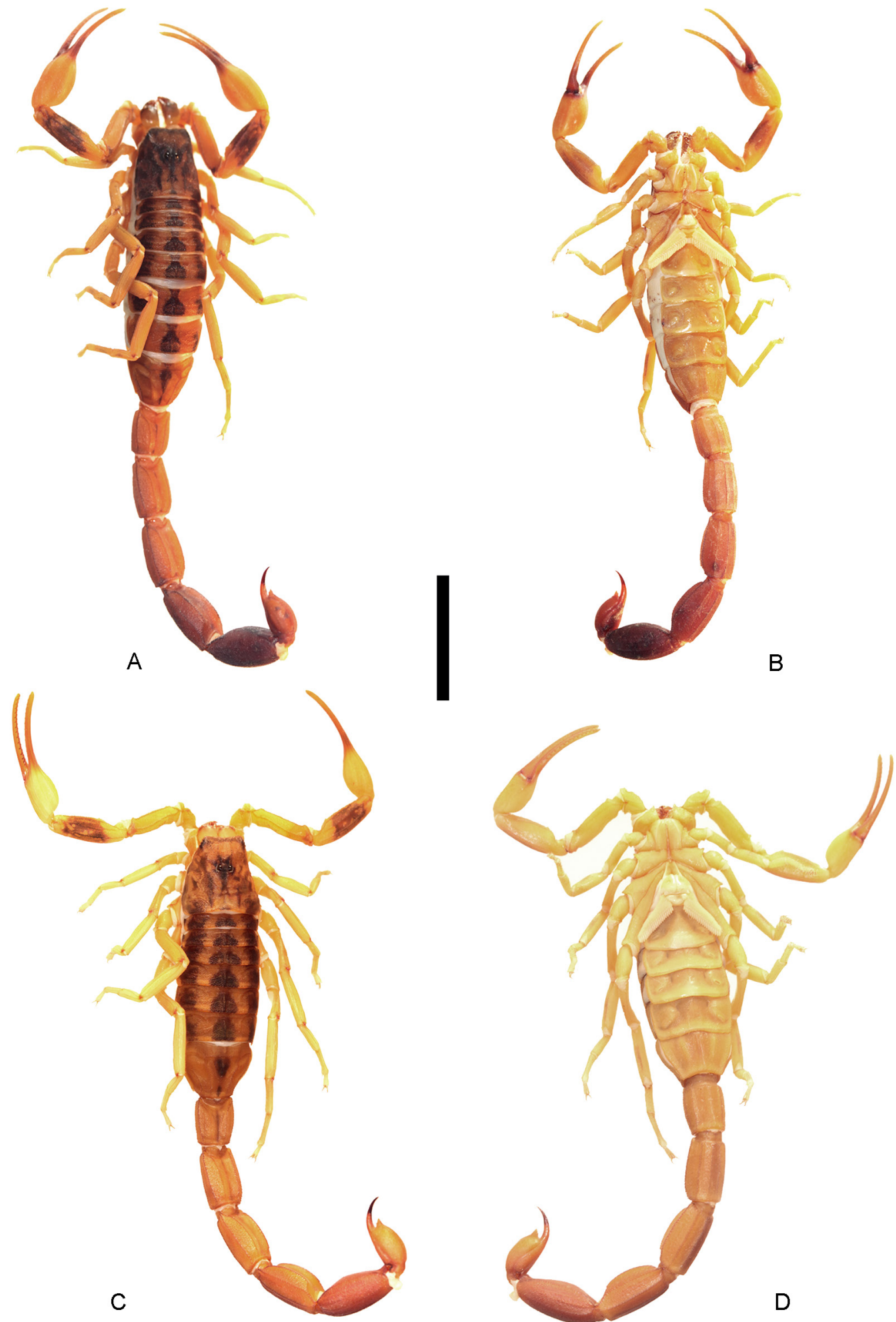

Fig. 3. Tityus carrilloi n. sp. Habitus, A, B. Holotype ơ. C, D. Paratype 9. A, C. Dorsal aspect. B, D. Ventral aspect. Scale bar: $10 \mathrm{~mm}$. 
that also fuses in its anterior margin with the transversal carina of pretergite.

Sternites. Sternite I finely granular near the lateral margins, with two VSM semi-transversal furrows joining near the anterior margin and surrounding a glandular subtriangular area, this gland is also delimitated by two carinae and a row of setae forming a triangular shape; this gland is more conspicuous in males than in females (Figs. 6A, B); with small, elliptical narrow or antero-posteriorly compressed spiracles. Sternite II: tegument finely granular, with a transversal row of four setae and one seta near each spiracle; with two small VSM furrows, with small, elliptical narrow spiracles. Sternite III: similar to II but with a well developed posteromedian subtriangular gland, more conspicuous in males. Sternite IV: similar to II but with two VSM longitudinal carinae occupying slightly more than the posterior half of the segment. Sternite V: tegument granular, with four longitudinal VSM carinae (Figs. 6A, B), the external carinae are placed in the median part of the segment occupying slightly more than a half of the segment, the internal carinae are longitudinal and occupy almost the whole segment, presenting a small curve in the anterior third surrounding a macroseta; in some specimens there is also a poorly developed VM carina in the anterior third of the segment.

Metasoma. Metasomal segment I: intercarinal surfaces finely granular; DL, LSM, LIM, VL and VSM carinae granular end extending the entire length of the segment; distal granules of the DL carinae of the same size and shape as the rest (Fig. 7E). Segment II similar to segment I but LIM carina is less developed, presenting fewer granules. Segments III and IV similar to segment II but the LIM carina becomes less developed in each segment, being absent or inconspicuous in segment IV; dorsally with a smooth median area, being more conspicuous in 9. Segment V, slightly more elongated than the rest of the segments, being oval shaped (Figs. $7 \mathrm{~A}, \mathrm{~B}, \mathrm{G})$, being clearly higher and wider in $\mathrm{o}^{7}$ than in $\%$ (Figs. 7A, B, G), length/height ratio, \%: 2.12-2.33 $(\mathrm{N}=10$; mean=2.22), ơ: 2.03-2.10 $(\mathrm{N}=4$; mean $=2.07)$; length/with ratio, o: 2.12$2.28(\mathrm{~N}=10$; mean=2.19), ơ: 1.97-2.10 $(\mathrm{N}=4$; mean $=2.02$ ), dorsolateral margin with a well developed carina, VL and VM carinae granular and extending the entire length of the segment (Fig. $7 \mathrm{G}$ ); with poorly developed VSM carinae, formed by tiny granules, but extending almost the entire length of the segment.
Telson. Vesicle oval, with the dorsal surface flatter in $\$$ and slightly convex in $0^{x}$ (Figs. 8A, B). Surface granular, with a poorly developed VM carina, and barely visible lateral carinae; with some scattered setae. Subaculear tubercle sub pyramidal, ventral margin smoothly serrated and connecting to the VM carina, base of the dorsal margin with two small but conspicuous and well separated granules. Aculeus strongly curved, basal part of the ventral margin with a well developed furrow.

Hemispermatophore. flageliform, typical of the subgenus. Slender (Figs. 8C, D, E). Pars reflexa poorly developed and highly curved, pars recta well developed and slightly curved medially. Lobe region well developed, internal lobe short, basal lobe hook-like, external lobe well developed, triangular, clearly separated from the hemispermatophore, median lobe small, barely protruding (Figs. 8C, D).

Distribution, ecology and synanthropic populations. Tityus carilloi $\mathrm{n}$. sp. occupies most parts of central and northern Argentina (Fig. 2). However, most of its distribution corresponds exclusively to synanthropic, parthenogenetic all-female populations, and not to records in nature. With the available and historic data we can assume that the original distribution of this species, corresponds to the area in which males and females can be found in natural environments, and that the synanthropic parthenogenetic populations are the result of a relatively recent process of invasion of this species into human settlements in the last century (Adilardi et al., 2014; Ojanguren-Affilastro et al., 2019).

The original distributional area of $T$. carrilloi $\mathrm{n}$. sp. seems to be restricted to a relatively small range of humid Argentinean Chaco, probably limited northerly by the Bermejo River (Fig. 2 ). Some all-female populations can be found in the wild in a slightly larger area of humid Argentinean Chaco, and we consider that this area could probably correspond to the original natural distribution of this species too. In both areas, also synanthropic all female parthenogenetic populations can be found.

Males of this species are remarkably scarce; we have had access to only four of them (among hundreds of specimens examined), each from a different population, from Chaco and Corrientes provinces, as well as to an old specimen from Buenos Aires, surely mislabeled (Maury, 1970). Additionally, a sexual population of this species has been cited from an area near the city of 


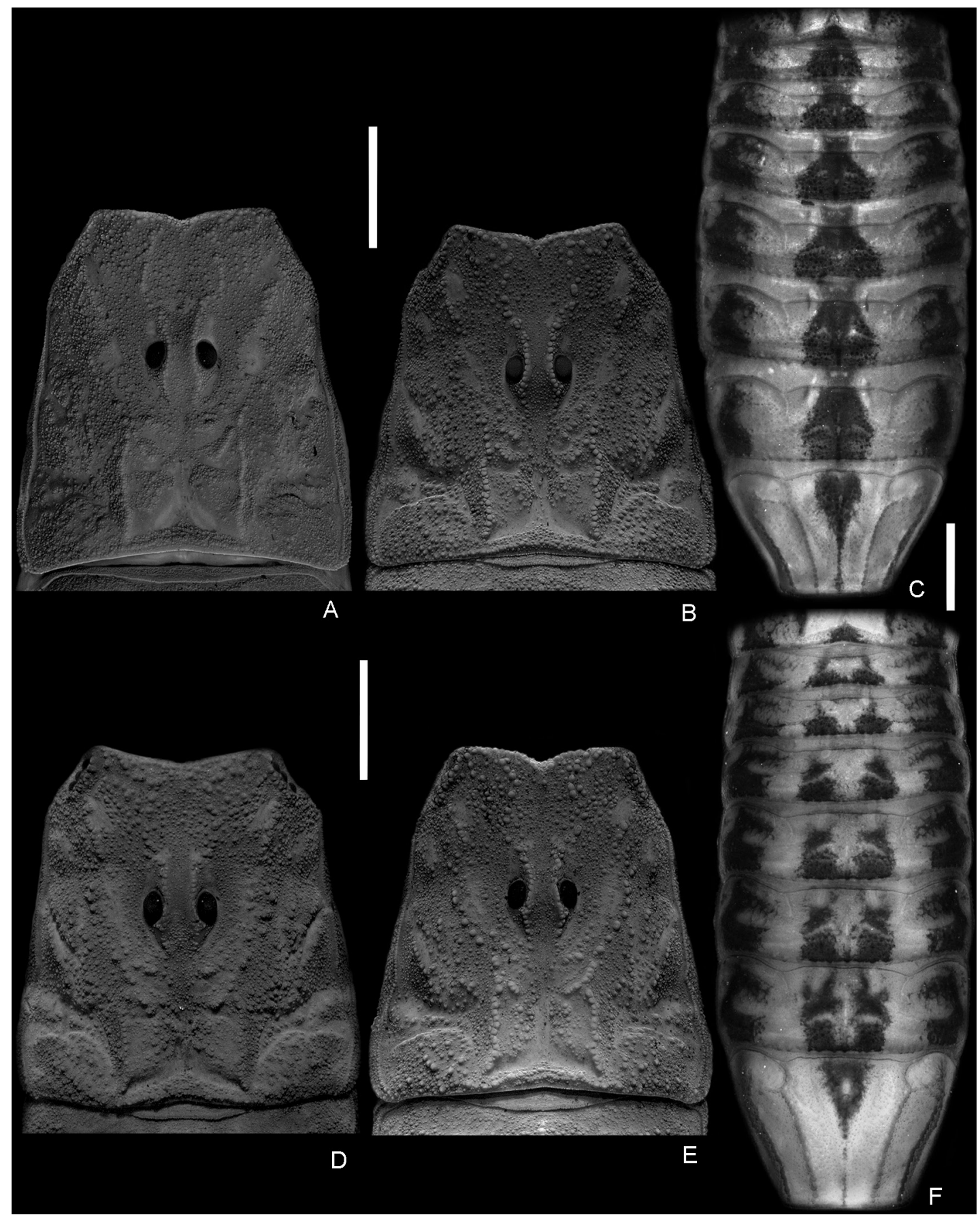

Fig. 4. A-C. Tityus carrilloi n. sp. A. Carapace ơ; B. Carapace 9 ; C. Tergites, pigment pattern. D-F. Tityus trivittatus. D. Carapace ơ; E. Carapace ; F. Tergites, pigment pattern. Scale bars: $1 \mathrm{~mm}$.

Corrientes (Seiter \& Stockman, 2017).

The invasive capability of $T$. carrilloi $\mathrm{n}$. sp. is remarkable since the use of human settlements allowed this species to reach areas with com- pletely different climates from those from where it originated. Due to the progression in the studies on this species performed during the last 70 years by different authors in Argentina, we know 
that it has extended its distribution about $300 \%$ in this period (Mello-Leitão, 1934, 1945; Maury, 1970; 1997; Murúa et al., 2002; FernándezCampón \& Lagos Silnik, 2009; Ojeda \& Neder, 2017; Ministerio de Salud, 2011; Ministerio de Salud Pública de la Provincia de Salta, 2011; Ojanguren-Affilastro et al., 2019; López et al., 2019). Most certainly this species has been passively transported by humans to all the cities out of the area of its original distribution.

Considering both natural and synanthropic populations, the distribution of this species seems to be restricted northerly by the Pilcomayo, Paraguay, and Paraná Rivers, reaching the northernmost part of Argentina in Jujuy, Salta, Formosa and Misiones provinces (Ojanguren-Affilastro et al., 2019). Apparently, it is not present yet in Bolivia, Paraguay, nor in Brazil; however due to its tremendous capability to expand by invading human settlements, its current presence or future colonization, in these countries as a synanthropic species cannot be ruled out. Westerly, this species has invaded cities placed in desert sub-Andean areas of Argentina, where the genus Tityus is not naturally present (Murúa et al., 2002; Fernández-Campón \& Lagos Silnik, 2009). However, it has not crossed the Andes mountain chain yet, which marks the Argentinean-Chilean border. The southernmost records of this species belong to Buenos Aires and La Plata cities (latitude: 34⿳050'S), being also the southernmost populations of a dangerous scorpion in the world, together with the recently arrived sympatric $T$. confluens (de Roodt et al., 2009; Ojanguren-Affilastro et al., 2019). This area presents a temperate climate, with temperatures in winter that can often reach $0^{0}$ Celsius; being very different to the subtropical Chaco where T. carrilloi n. sp. belongs. Due to this, during the colder period of the year, these southernmost populations are restricted to the underground structures of the city (subways, basements, sewers etc.), which preserve a warmer temperature even in winter; only during the summer this species appears at the surface in the city. This dependence on a warmer underground in winter, has restricted the distribution of this species in this latitude to highly urbanized areas, not being present in the outskirts of the city.

Outside Argentina, T. carrilloi n. sp. is only present in Uruguay. The Uruguay River seems to be a natural barrier for this species, and most probably it has been recently introduced there from Argentina. All known records in this country belong to the area close to the city of
Colonia de Sacramento (Toscano-Gadea, 2012), in Southwestern Uruguay, which is probably the most important port between Argentina and Uruguay.

\section{Tityus trivittatus Kraepelin, 1898 (Figs. 1, 2, 4, 6, 7, 9-11)}

Tityus trivittatus Kraepelin, 1898: 43-44. Type material: 2 syntypes ơ, Paraguay, San Salvador (ZMH).

References. Tityus trivittatus: Borelli, 1899: 4-5 (part); Kraepelin, 1899: 74, 83; Borelli, 1901: 5-6 (part); Kraepelin, 1901: 269; Werner, 1902: 600; Kraepelin, 1908: 193; Penther, 1913: 240; Lutz \& Mello, 1922: 5,8; Mello-Campos, 1924a: 270; Mello-Campos, 1924b: 336; Mello-Leitão, 1931: 128,129, 144 (part); Mello-Leitão, 1932: 17, 18, 29 (part); Toledo-Piza, 1932: 302; MelloLeitão, 1934: 22, 23 (part); Mello-Leitão, 1938: 93-95 (part); Mello-Leitão, 1939a: 62, 64, 73; Mello-Leitão, 1939b: 611; Mello-Leitão, 1945: 300, 364-367; Weidner, 1959: 104; Bucherl, 1964: 59 (part); Bücherl, 1969: 768 (part); Maury, 1970: 405-421(part); Bücherl, 1971: 327, 330, 332 (part); Maury, 1974: 89, 91 (part); Lourenço, 1980: 793-840 (part); Lourenço, 1982: 1-4; Maury, 1984: 216; Lourenço, 1994: 680, 681; Lourenço, 1997: 596 (part); Maury, 1997: 1-21 (part); Kovarik, 1998: 122. Lourenço, 2001: 160, 161, 166 (part); Toscano-Gadea, 2004: 866-869 (part); Ojanguren-Affilastro, 2005: 92-94 (part); Lourenço, 2006: 60; Toscano-Gadea, 2012: 83, 86, 87 (part); Adilardi et al., 2014: 81-88 (part); Guerrero \& Kochalka, 2015: 62, 63, 64 (part); Carvalho et al., 2017: 1-6 (part.); Faúndez \& Albornoz, 2017: 165, 166 (part.); OjangurenAffilastro et al., 2017a: 44, 45 (part.); OjangurenAffilastro et al., 2017b: 6, 11, 13 (part.); Seiter \& Stockmann, 2017: 155-158, 160-163 (part); Borges \& Rojas de Arias, 2019: 27-35 (part); Ojanguren-Affilastro et al., 2019: 101, 102, 104, 105 (part.); Borges et al., 2020a: 2, 10, 15, 18, 21 (part).

Tityus trivittatus trivittatus. Mello-Leitão, 1945: 310 (part); Bücherl, 1959: 260; Maury, 1970: 406-414 (part); Maury, 1974: 85; 89, 91 (part.); Bücherl, 1978: 372; Lourenço, 1979: 37-45 (part); Maury, 1979: 705 (part); Lourenço, 1980: 797, 798, 839 (part.).

Diagnosis and comparisons. A medium sized species of Tityus belonging to the trivittatus 


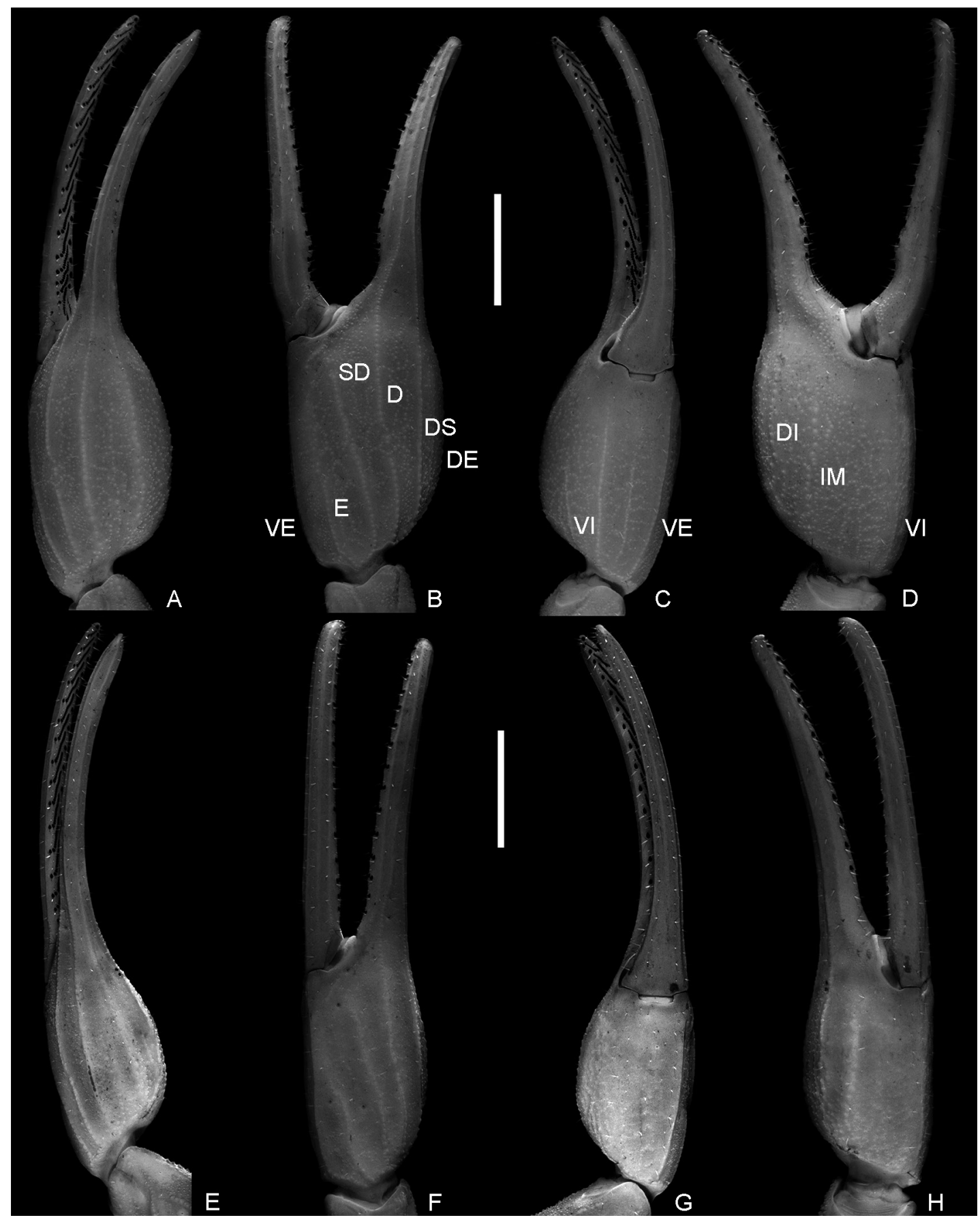

Fig. 5. A-H. Tityus carrilloi n. sp. A-D. Left pedipalp chela, ơ. A. Dorsal aspect. B. External aspect. C. Ventral aspect. D. Internal aspect. E-H. Left pedipalp chela, o. E. Dorsal aspect. F. External aspect. G. Ventral aspect. H. Internal aspect. DI: dorsal internal; DE: dorsal external; VI: ventral internal; VE: ventral external; D: digital; E: external; IM: interno median; DS: dorsal secondary; SD: sub digital. Scale bars: $1 \mathrm{~mm}$.

complex and to the nominotypical subgenus. Tityus trivittatus is most closely related to $T$. carrilloi and T. confluens. Tityus trivittatus can be separated from $T$. confluens by their pigmentation pattern. In T. trivittatus tergites I-VI bear three pigment spots two lateral and one median, 


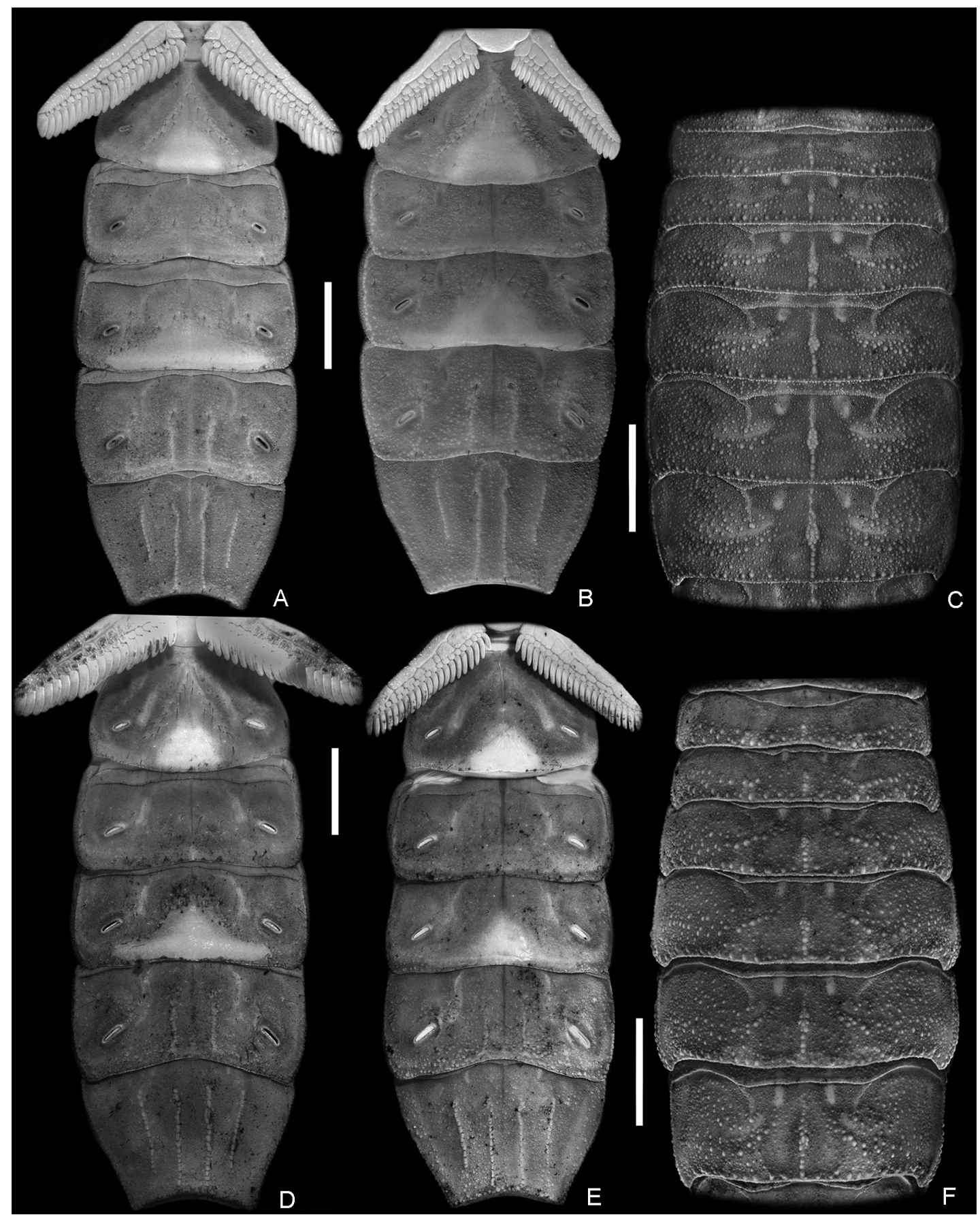

Fig. 6. A-C. Tityus carrilloi n. sp. A. Sternites and pectines ơ; B. Sternites and pectines ; C. Tergites. D-F. Tityus trivittatus. D. Sternites and pectines ơ; E. Sternites and pectines $\%$; F. Tergites. Scale bars: $10 \mathrm{~mm}$.

whereas in T. confluens tergites I-VI are completely covered by pigment. To see the diagnostic characters separating T. trivittatus from T. carrilloi $\mathrm{n}$. sp. see the diagnosis of this species.
Redescription. Based on the syntypes $(\mathrm{ZMH})$, and material from the IBNP and MACN. Total length: $53.00-66.00 \mathrm{~mm}(n=9 ;$ mean $=57.00)$ in ơ; $55.00-66.50 \mathrm{~mm}(n=5 ;$ mean $=63.50)$ in . 


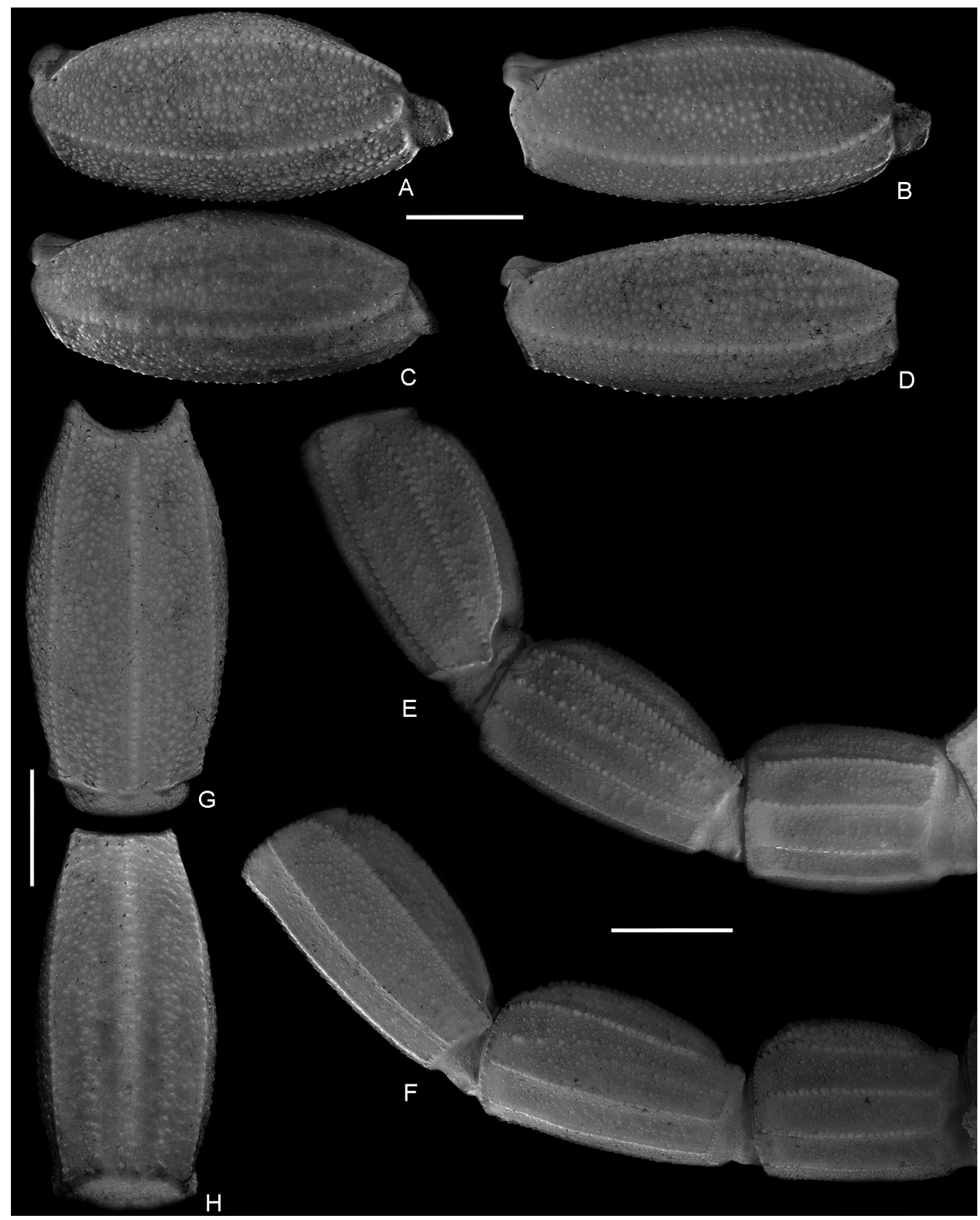

Fig. 7. A, B, E, G. Tityus carrilloi n. sp. A. Metasomal segment V, ơ, lateral aspect; B. Metasomal segment V $q$, lateral aspect; E. metasomal segments I-III, ơ, lateral aspect; G. Metasomal segment V, ơ, ventral aspect. C, D, F, H. Tityus trivittatus C. Metasomal segment V, ơ, lateral aspect; D. Metasomal segment V \%, lateral aspect; F. metasomal segments I-III, ơ, lateral aspect; H. Metasomal segment V, ơ,ventral aspect. Scale bars: $1 \mathrm{~mm}$.

Colour: Base colour yellowish, with dark brown pattern in chelicerae, carapace and tergites (Figs. 9A-D). Chelicerae: light yellow with a dense re- ticulate pattern in manus and movable finger. Carapace: with black areas around ocular tubercle and lateral eyes; with a dark triangle ranging 


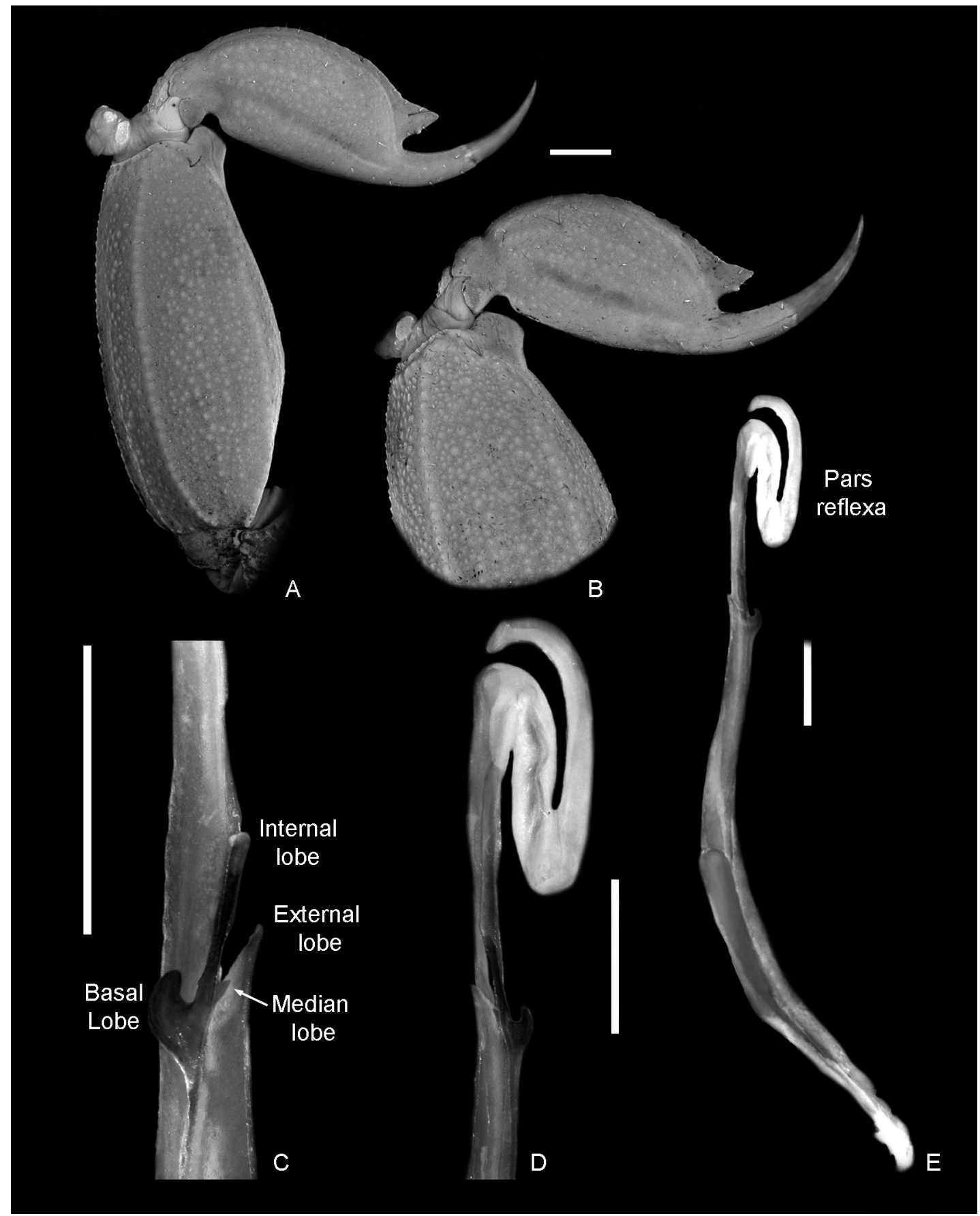

Fig. 8. A-E. Tityus carrilloi n. sp. A, B. Telson. A. \&, lateral aspect. B. ơ, lateral aspect. C-E. left hemispermatophore. C. Internal aspect; d. detail of the lobe region and pars reflexa; E. Detail of the lobe region. Scale bars: $1 \mathrm{~mm}$.

from the posterior margin of the ocular tubercle to the frontal margin; lateral areas with dark reticular pattern connecting with two posterolateral dark spots and surrounding a median area almost devoid of pigment. Tergites I-VI (Fig. 4F) each with three dark spots extending the entire length of the segment, two lateral, and a median dark spot; these spots are not connected to 

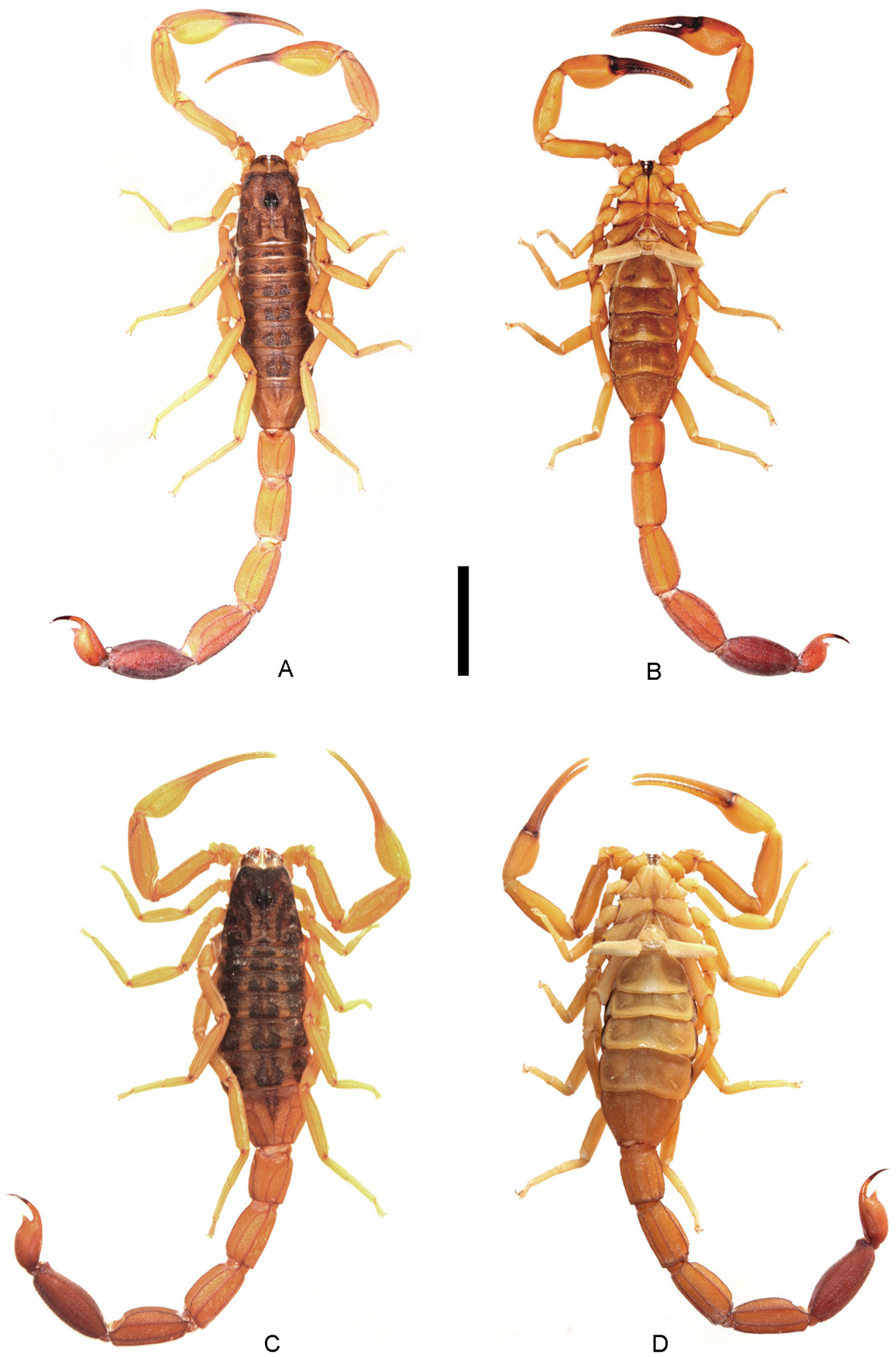

Fig. 9. Tityus trivittatus. Habitus, A, B. ơ. C, D. ९. A, C. Dorsal aspect. B, D. Ventral aspect. Scale bar: $10 \mathrm{~mm}$. 
each other, leaving two relatively narrow unpigmented stripes, the median spot is generally subquadrangular, but in some specimens tends to be subtriangular; in all cases this spot presents a median unpigmented area, which in some cases divides the median spot into two separated spots; lateral spots $\mathrm{C}$ shaped, but usually with some reticular pigment in its median area. Tergite VII only with a median elongated subtriangular stripe, with a wider anterior margin and a thin posterior margin. Sternites, sternum, genital opercula and pectines unpigmented. Metasomal segments I-IV general colour yellowish, without any pigment pattern. Metasomal segment IV general colour reddish, without any pigment pattern. Telson, vesicle general colour reddish, aculeus dark brown. Pedipalps: femur and patella unpigmented; chela manus unpigmented; fingers reddish brown (Fig. 9A-D). Legs: unpigmented.

Carapace. Anterior margin with a conspicuous broad median notch that divides the anterior margin into two lobes. Surface densely granular, more so in the lateral margins. Anteromedian longitudinal sulcus shallow; interocular sulcus, posteromedian, longitudinal, and lateral sulci present and conspicuous. Median ocular tubercle well developed and clearly protruding above carapace in lateral profile; median ocelli well developed, approximately one diameter apart. Three small lateral ocelli on each side of carapace. Anterior median carinae, median ocular carinae, lateral carinae, and posterior carinae all granular and well developed (Figs. 4D, E).

Chelicerae. Tegument densely granular, especially near the distal margin, more so in males. Dentition typical for the genus. Teeth well developed.

Pedipalps. Femur, intercarinal surfaces densely granular except for the ventral surface which is barely granular. With smooth parts; DE, DI, VE and VI carinae granular and well developed, extending the entire length of the segment; internal margin with a well developed internal-median (IM) carina extending the entire length of the segment. Patella intercarinal surfaces sparsely granular DI, DM, DE, IM VI, $\mathrm{VE}$ and EM carinae granular, extending the entire length of the segment, proximal two or three granules of IM carinae are approximately twice bigger than the rest. Chela manus slender, being more robust in $\sigma^{\prime}$, length/height ratio, ?: $4.78-5.57(\mathrm{~N}=5$; mean $=5.19)$, or: $3.85-4.31$ $(\mathrm{N}=9$; mean $=4.14)$; length/width ratio,, : 5.19 $5.57\left(\mathrm{~N}=5\right.$; mean=5.36), o ${ }^{*}: 3.85-4.31(\mathrm{~N}=9$; mean=4.14), DI, DE, DS, D, SD, E, VE, and IM carinae granular and well developed, VI carina granular but less developed (Figs. 10A-H); fixed and movable fingers thin, elongated and slightly curved internally; movable finger with 16 , or 17, sub-parallel barely transversal denticle rows (Fig. 10A), being the basal row longitudinal basally and sometimes formed by the fusion of two denticle rows; fixed finger with 14-16 sub-parallel denticle rows (Fig. 10C), being the basal row longitudinal and always formed by the fusion of two or three denticles rows; each of these denticles rows presents an apical enlarged tooth and two basal enlarged teeth, which are two or three times bigger than the rest of the denticles; the apical enlarged tooth presents one hyaline and one chitinized seta in the base of it; the most apical of the basal enlarged denticles presents a single hyaline seta in its base, and the most basal presents a chitinized seta in its base; at the apical margin of each finger there is an apical tooth with two lamellar, and two wide setae surrounding its basal margin. Movable finger with a basal lobe well developed in o (Figs. 10B, D), absent or inconspicuous in 9 (Figs. 10F, H); fixed finger straight in $\$$, with a small notch facing the basal lobe in on. Trichobothrial pattern orthobothriotaxic type A; femur with 11 trichobothria, $\alpha$ configuration and trichobothria $d 2$ placed on the internal surface; patella with 13 trichobothria; chela with 15 trichobothria, being esb petit.

Legs. Intercarinal surfaces finely granular. Carinae granular, extending the entire length of the segment. Basitarsi each with two well developed, equal-length pedal spurs; the external one is bicuspid and presents an external very well developed macroseta. Telotarsi short, ventrally with abundant chitinized setae and 3/3 VL hyaline setae. Pseudoniquium elongated. Ungues medium sized, equal in length and poorly curved.

Sternum. Sub-triangular, being slightly wider in females.

Genital opercula. Medium sized. Sclerites with a general subtriangular shape but with a curved anterior margin, in $\$$ the posterior margin of the sclerites is also curved, whereas in or it is almost straight and perpendicular to the axis of the body.

Pectines. With a single row of median lamellae; first median lamella more or less similar in size in $\sigma^{\prime}$ and 9 (Figs. 6D, E). Fulcra present, small and subcircular. Pectinal teeth medium sized; tooth count: $19-23$ in $\sigma^{7}(\mathrm{n}=9$; median $=$ $21), 19-21$ in ? $(n=5$; median $=20)$.

Tergites. Pretergites with fine granulation in $\sigma^{x}$, more densely granular in $\%$, separated from 


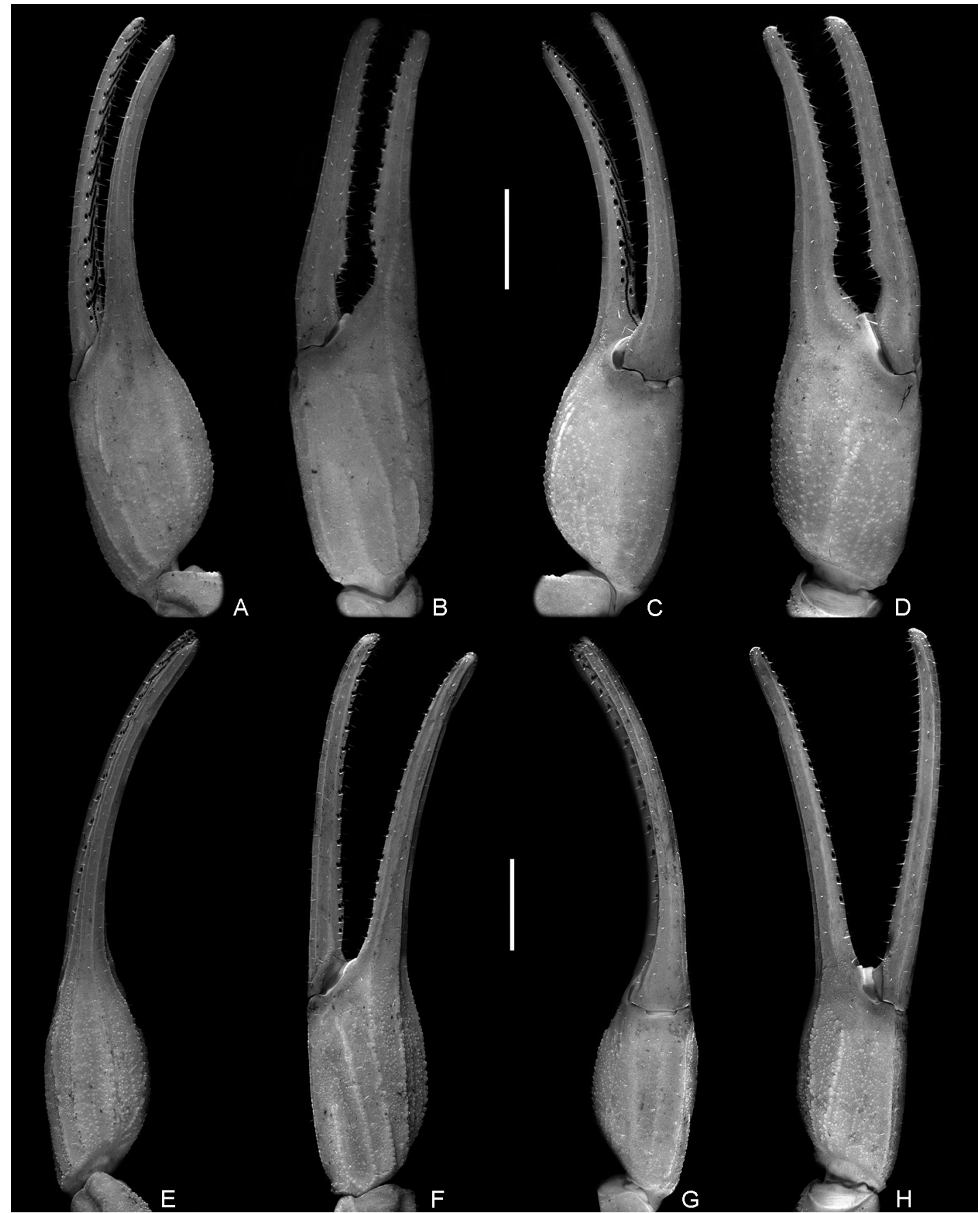

Fig. 10. A-H. Tityus trivittatus. A-D. Left pedipalp chela, ơ. A. Dorsal aspect. B. External aspect. C. Ventral aspect. D. Internal aspect. E-H. Left pedipalp chela, ๆ. E. Dorsal aspect. F. External aspect. G. Ventral aspect. H. Internal aspect. Scale bars: $1 \mathrm{~mm}$.

the rest of the tergite by a well developed anterior transversal carina. Tergites I-VI, surfaces granular being more coarse so in the posterior half of the segment, with a barely visible in- complete transversal carina separating anterior and posterior halves of each tergite; with a dorsal-median longitudinal carina extending from the posterior margin to the median part of the 
tergite, not reaching the pretergite (Fig. $6 \mathrm{~F}$ ); the dorsal median carina is formed by a single row of granules in the posterior margin of the segment, and becomes double in the median part of the tergite; the dorsosubmedian carinae are not conspicuous, being represented by small keels barely protruding from the pretergite transversal carina in posterior segments, or by a single posterior granule in anterior segments; posterior margin with some coarse sparse granules. Tergite VII surfaces granular, dorsal-median carina extending the median half of the segment, not reaching the pretergite nor the posterior margin, formed by a double row of granules in its anterior half, fusing in a single row in the second half; with four longitudinal dorsosubmedian carinae extending the entire length of the segment, fusing anteriorly to each other in a subcircular transversal carina, that also fuses in its anterior margin with the transversal carina of pretergite.

Sternites. Sternite I granular, with two VSM semi-transversal furrows joining near the anterior margin and surrounding a glandular subtriangular area, this gland is also delimitated by a carina, less developed in $\sigma^{*}$, and a row of setae, all forming a triangular shape; this gland is more conspicuous in males than in females (Figs. 6D, E); with elliptical spiracles. Sternite II: tegument finely granular, with a transversal row of four setae and one seta near each spiracle; with two small VSM furrows joining anteriorly in the presternite transversal carina, and forming a semicircle, with elliptical spiracles. Sternite III: similar to II but with a well developed posteromedian, subtriangular gland, more conspicuous in males. Sternite IV: similar to II but with two VSM longitudinal carinae occupying slightly more than the posterior half of the segment. Sternite V: tegument granular, with four longitudinal VSM carinae (Figs. 6D, E), the external carinae are placed in the median part of the segment occupying slightly more than a half of the segment, the internal carinae are longitudinal and occupy almost three quarters of the segment, being double in the anterior margin, surrounding a macroseta.

Metasoma. Metasomal segment I: intercarinal surfaces finely granular; DL, LSM, LIM, VL and VSM carinae granular end extending the entire length of the segment; distal granules of the DL carinae equal in size and shape as the rest. Segment II similar to segment I but LIM carina is very reduced, usually restricted to some granules in the posterior third of the segment (Fig. 7F). Segments III and IV similar to segment II but the LIM carina is absent, and the DL carina fuses posteriorly with the LSM carina; dorsally finely granular. Segment V, slightly more elongated than the rest of the segments, being oval shaped, being higher and wider in $0^{*}$ than in $\%$ (Figs. 7C, D, H), length/height ratio, o: $2.23-2.35(\mathrm{~N}=5 ;$ mean $=2.31), o^{x}: 2.03-2.28$ $(\mathrm{N}=9$; mean $=2.15)$; length/with ratio, $\%: 2.12-$ $2.28(\mathrm{~N}=5 ;$ mean=2.20), ơ : 2.00-2.21 $(\mathrm{N}=9$; mean $=2.10$ ); surface densely granular, dorsolateral margin with a poorly developed but complete carina, VL and VM carinae granular and extending the entire length of the segment (Fig. $7 \mathrm{H}$ ); with barely visible VSM carinae, formed by tiny granules, but extending almost the entire length of the segment.

Telson. Vesicle oval, with the dorsal surface flatter in $\$$ and slightly convex in $\sigma^{7}$ (Figs. 11A, B). Surface granular, with a poorly developed VM carina, and barely visible lateral carinae; with some scattered setae. Subaculear tubercle subpyramidal, ventral margin smoothly serrated and connecting to the VM carina, base of the dorsal margin with two small but conspicuous and well separated granules. Aculeus strongly curved, basal part of the ventral margin with a well developed furrow.

Hemispermatophore. flageliform, typical of the subgenus. Slender (Fig. 11E). Pars reflexa poorly developed and highly curved, pars recta well developed and slightly curved medially. Lobe region well developed, internal lobe short, basal lobe hook-like, external lobe well developed, triangular, clearly separated from the hemispermatophore, median lobe small, barely protruding (Figs. 11C, D).

Distribution and Ecology. Tityus trivittatus occurs in a relatively wide region of eastern Paraguay and southern Brazil, in a mosaic of environments of wet Chaco, Cerrado and Atlantic Forest, (with a predominance of the first). This is also a synanthropic species, being common in the city of Asunción, where it is sympatric with T. confluens (Guerrero \& Kochalka, 2015; Borges \& Rojas de Arias, 2019). Its distributional limits seem to be represented by the Pilcomayo, Paraguay and Paraná rivers, in south, east and west of its distribution (Fig. 2); the northernmost limit of this species is not yet clearly established, but northernmost records are approximately at $17^{\circ} \mathrm{S}$ in latitude (Maury, 1970; Lourenço, 1980; Carvalho et al., 2017). Up to now this species has not been collected in Argentina, where it is most certainly not present in natural environments; however due to its 


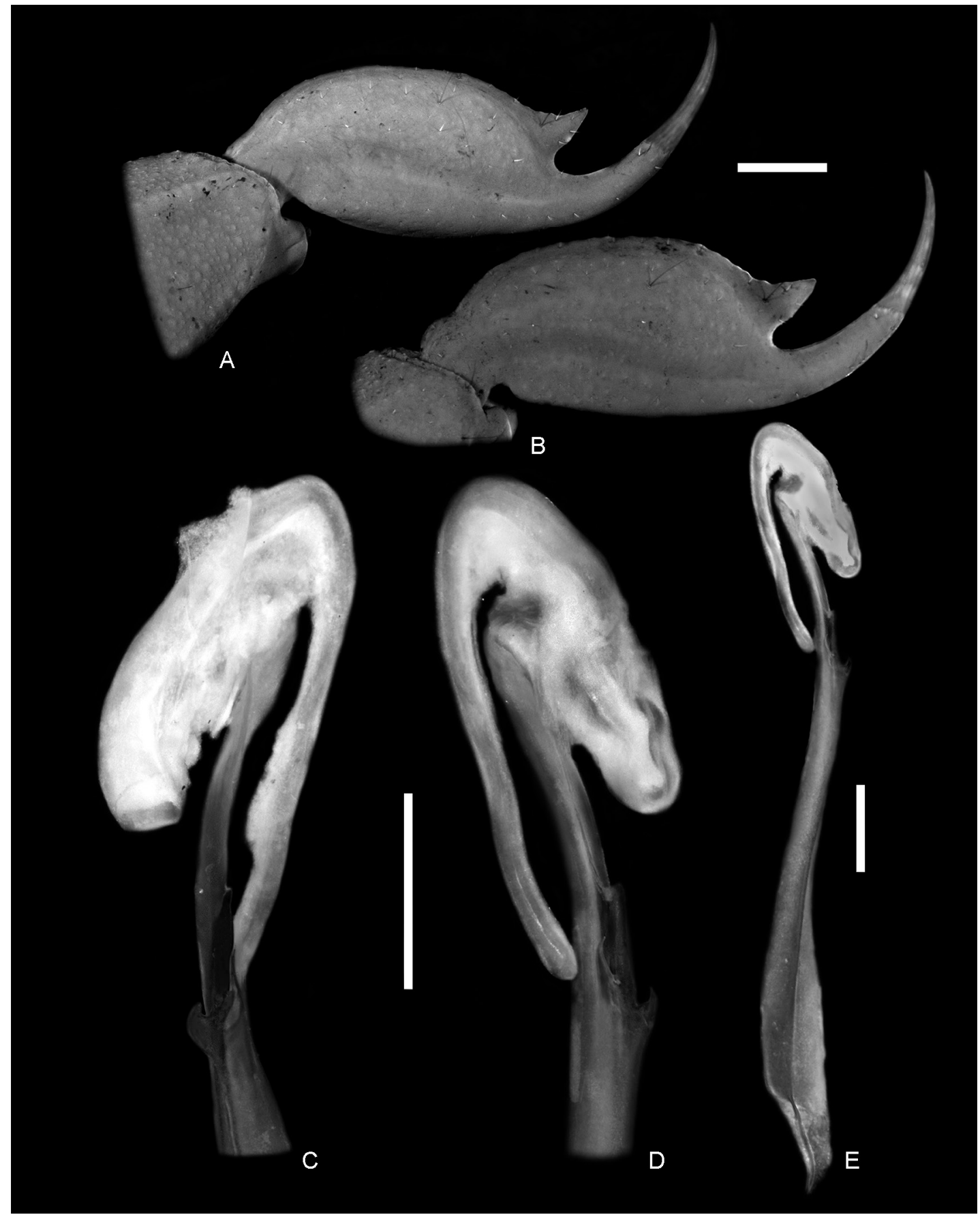

Fig. 11. A-E. Tityus trivittatus. A, B. Telson. A. \%, lateral aspect. B. ơ, lateral aspect. C, D. left hemispermatophore. C. Internal aspect; D. detail of the lobe region and pars reflexa, lateral aspect; E. Right hemispermatophore, detail of the lobe region and pars reflexa, internal aspect. Scale bars: $1 \mathrm{~mm}$.

synanthropic capabilities, it could be passively introduced in Argentina as some specimens of $T$. serrulatus (Camargo \& Ricciardi, 2000; López et al., 2019). Contrary to T. carrilloi n. sp. all, nat- ural and synanthropic populations of this species have both, males and females in similar proportions, and up to now we have not found evidences of parthenogenetic populations of T. trivittatus. 
Table 1. Measurements ( $\mathrm{mm}$ ) of Tityus carrilloi $\mathrm{n}$. sp. (holotype $\delta$ and paratype + , MACN), and Tityus trivittatus Kraepelin, 1898 ( $\widehat{\partial}$ and + , IBNP).

\begin{tabular}{|c|c|c|c|c|}
\hline & \multicolumn{2}{|c|}{ Tityus carrilloi $\mathrm{n}$. sp. } & \multicolumn{2}{|c|}{ Tityus trivittatus } \\
\hline & Holotype $\delta^{\lambda}$ & Paratype $q$ & 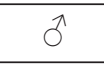 & o \\
\hline Total length & 53.70 & 49.90 & 59.60 & 61.80 \\
\hline Carapace, length & 6.00 & 6.00 & 6.70 & 6.80 \\
\hline Carapace, anterior width & 3.00 & 3.00 & 3.50 & 3.50 \\
\hline Carapace, posterior width & 5.50 & 5.90 & 6.40 & 6.90 \\
\hline Mesosoma, total length & 16.70 & 15.00 & 16.80 & 20.50 \\
\hline Metasoma, total length & 25.40 & 23.60 & 29.60 & 28.50 \\
\hline Metasomal segment I, length & 3.50 & 3.40 & 4.00 & 4.00 \\
\hline Metasomal segment I, width & 3.00 & 2.85 & 3.40 & 3.30 \\
\hline Metasomal segment I, height & 3.00 & 2.60 & 2.90 & 3.00 \\
\hline Metasomal segment II, length & 4.60 & 4.30 & 5.10 & 5.30 \\
\hline Metasomal segment II, width & 3.10 & 2.70 & 3.40 & 3.20 \\
\hline Metasomal segment II, height & 2.80 & 2.50 & 2.90 & 3.00 \\
\hline Metasomal segment III, length & 5.20 & 4.60 & 5.90 & 5.50 \\
\hline Metasomal segment III, width & 3.20 & 2.70 & 3.40 & 3.20 \\
\hline Metasomal segment III, height & 2.80 & 2.50 & 3.00 & 2.80 \\
\hline Metasomal segment IV, length & 5.50 & 5.30 & 6.90 & 6.20 \\
\hline Metasomal segment IV, width & 3.30 & 2.65 & 3.50 & 3.20 \\
\hline Metasomal segment IV, height & 2.90 & 2.50 & 3.20 & 3.00 \\
\hline Metasomal segment $\mathrm{V}$, length & 6.60 & 6.00 & 7.70 & 7.50 \\
\hline Metasomal segment V, width & 3.50 & 2.70 & 3.70 & 3.20 \\
\hline Metasomal segment $\mathrm{V}$, height & 3.30 & 2.70 & 3.50 & 3.20 \\
\hline Telson, length & 5.60 & 5.30 & 6.50 & 6.00 \\
\hline Vesicle, length & 3.30 & 3.30 & 4.00 & 3.90 \\
\hline Vesicle, width & 2.50 & 2.00 & 1.90 & 2.30 \\
\hline Vesicle, height & 2.15 & 2.00 & 2.35 & 2.15 \\
\hline Aculeus, length & 2.30 & 2.00 & 2.50 & 2.10 \\
\hline Femur, length & 6.00 & 5.70 & 6.70 & 6.90 \\
\hline Femur, width & 1.60 & 1.55 & 1.80 & 1.80 \\
\hline Patella, length & 6.20 & 6.00 & 7.30 & 7.10 \\
\hline Patella, width & 2.10 & 2.00 & 2.30 & 2.30 \\
\hline Chela, length & 11.00 & 9.90 & 13.00 & 11.80 \\
\hline Chela, width & 2.60 & 1.95 & 3.30 & 2.50 \\
\hline Chela, height & 2.80 & 1.80 & 3.30 & 2.30 \\
\hline Movable finger, length & 6.90 & 6.90 & 8.50 & 8.00 \\
\hline
\end{tabular}




\section{Dated phylogenetic analysis}

The split between $T$. trivittatus, from $T$. carrilloi n. sp., and T. confluens, occurred about 3.1 million years ago (mya; 0.5-5.6, 95\% Highest Posterior Density - HPD), whereas the split between $T$. confluens and T. carrilloi occurred more recently, about 2.4 mya $(0.6-4.4,95 \%$ HPD) (Fig. 1) (Appendix S2).

In our analysis Tityus carrilloi $\mathrm{n}$. sp. appears as more closely related to $T$. confluens than to $T$. trivittatus, with which it has been mistaken.

As expected, Tityus trivittatus is nested inside the trivittatus complex (Ojanguren-Affilastro et al., 2017a); however, it has to be taken in consideration that this group was actually mostly based in T. carrilloi n. sp., which up to now was confused with $T$. trivittatus.

\section{DISCUSSION}

\section{On the Chacoan origin of T. carrilloi n. sp., T. trivittatus and T. confluens}

As stated in a previous contribution (Ojanguren-Affilastro et al., 2017a), the diversification process of the Chacoan species of the trivittatus complex is congruent with the last retrogression of the Paranaense sea, that occupied the south-central area of South America between 20 and five mya (Donato et al., 2003). Most part of the emerged large areas of land that appeared after the retrogression of this sea in late Pliocene, were eventually occupied by the actual Chaco. All southern species of the trivittatus complex are closely related to northern species of the nominotypical subgenus (Fig. 1), and seem to have evolved after dispersal in these recently emerged lands following a northern-southern pattern of distribution through the Chaco-CerradoCaatinga corridor (Lourenço 1986; OjangurenAffilastro et al., 2017a). A similar contemporary process through the same corridor has also been observed in Chacoan species of genera Ananteris and Zabius (Ojanguren-Affilastro et al., 2017a). On the other hand, Chacoan species of Bothriurid genus Brachistosternus Pocock, 1893 also settled in this area more or less in the same period, but following a different Andean route (Ceccarelli et al., 2016; Ojanguren-Affilastro et al., 2015).

The distribution of T. trivittatus and T. carrilloi $\mathrm{n}$. sp. in relatively similar environments of Humid Chaco, but clearly separated by the large rivers of the region, is congruent with a process of allopatric speciation, in which these rivers could have acted as vicariant barriers. Tityus confluens on the other hand, occurs, in general, more west- erly than the above-mentioned species, mostly in areas of dry Chaco, where it seems to have originated. Records of this species in sympatry with T. trivittatus and T. carrilloi $\mathrm{n}$. sp. in anthropized areas seem to be due to recent colonization of $T$. confluens as a synanthropic species (OjangurenAffilastro et al., 2019).

\section{Epidemiologic implications of the descrip- tion of T. carrilloi n. sp., and characteris- tics of the venom of $T$. carrilloi $n$. sp. and T. trivittatus}

The description of T. carrilloi as a new separate species from T. trivittatus, despite being by far, the most studied scorpion species of its area of influence, reveals the important gaps that still occur in South American scorpion knowledge. Additionally, it reveals how some misconceptions can be established and sustained through time when there are no further re-evaluations of the available data.

The scorpionism problem due to T. carilloi $\mathrm{n}$. sp. and T. trivittatus, from now on should be considered separately, taking into consideration the biological and phylogenetic differences between species.

Tityus carrilloi $\mathbf{n}$. sp. The toxicity of the venom of T. carrilloi n. sp. is clinically similar in human envenoming (de Roodt et al. 2003), and experimental envenomation (de Roodt et al., 2001, 2010), to those described for other Tityus species of the nominotypical subgenus of sanitary importance. Its toxicity is in the range of that described for other closely related species; toxicity in $20 \mathrm{~g}$ mice is around $0.6 \mu \mathrm{g} / \mathrm{g}$, but may vary in a range from 0.2 to $1.6 \mu \mathrm{g} / \mathrm{g}$ (de Roodt et al. 2010, 2019), and an important variation in toxicity, up to three fold, was observed in the venom from specimens of the same region (de Roodt et al., 2019). The electrophoretic profiles of the venom of T. carrilloi n. sp. showed interpopulational differences biochemically and immunologically. Remarkably, the toxicity of the venom of the population of T. carrilloi $\mathrm{n}$. sp. from the area of Buenos Aires city, the biggest urban area occupied by this species, is comparably lower to those from other regions (de Roodt et al., 2010, 2014, 2019); most probably due to this it has not caused deaths yet in Buenos Aires despite the relatively high number of accidents in the area. The reason for this lower toxicity has not yet been explained, but it has to be highlighted that the population from Buenos Aires represents the southernmost extreme of distribution for this species (and the genus), and is relatively isolated from other pop- 
ulations (Ojanguren-Affilastro et al,. 2019).

Several toxins from the venom of T. carrilloi $\mathrm{n}$. sp. were already isolated, like those that block $\mathrm{K}^{+}$channels (Coronas et al., 2003; AbdelMottaleb et al., 2006; Saucedo et al., 2012), and toxins that modulate $\mathrm{Na}^{+}$channels (Coronas et $a l ., 2015)$. The toxicity of this venom would be related with the last type of toxin (Possani et al., 1999). The first $\mathrm{Na}^{+}$-channel toxin isolated from the venom of $T$. carrilloi $\mathrm{n}$. sp. (originally described as for T. trivittatus), was called Tt1g (Tityus trivittatus toxin 1 gamma like), and has a 95\% of homology with the gamma toxin of $T$. serrulatus (Coronas et al., 2015). The к-buthitoxinTt2b (к-BUTX-Tt2b) shows structural versatility among this type of toxins (Saucedo et al., 2012), and the Tt28 was the first example of a new sub-family of toxins (a-KTx20.1), which might serve as a potential candidate for immunomodulation studies due its action in $\mathrm{K}^{+}$channels of T-lymphocytes (Abdel-Mottaleb et al., 2006). The TtButantoxin (TtBut-Toxin) isolated from T. $c a-$ rrilloi n. sp., acts on Shaker B- $\mathrm{K}^{+}$channels and is identical to TsTX-IV from $T$. serrulatus (Coronas et al., 2003).

Possibly these similarities in some toxins present in the venoms of T. carrilloi $\mathrm{n}$. sp. and $T$. serrulatus, especially regarding $\mathrm{Na}^{+}$blockers channels toxins (Coronas et al., 2015), are responsible for the important experimental cross reactivity observed assaying therapeutic antivenoms of both species (de Roodt et al. 2010), and of the success observed using anti-T. serrulatus antivenom in cases of envenomation by $T$. carrrilloi n. sp. (de Roodt et al,. 2003; Ministerio de Salud, 2011). However, the venoms are not identical, and consequently the antivenoms, although very useful due the paraspecific neutralization, have not the same reactivity, nor neutralizing capacity, regarding the specific antivenom (de Roodt et al., 2001,2010 ). The antivenom natively produced in Argentina using venom from T. carrilloi $\mathrm{n}$. sp. as immunogen, showed experimentally higher immunochemical reactivity (de Roodt et al., 2010), and neutralizing capacity, on the homologous venom regarding anti-Tityus serrulatus antivenom in neutralization experiments, showing better $\mathrm{ED}_{50}$ in experiments on mice challenged with $5 \mathrm{LD}_{50}$ of venom (de Roodt et al., 2001).

Tityus trivittatus. Scorpionism by T. trivittatus is an emerging problem in Paraguay, which is not currently subject to mandatory reporting, as opposed to Argentina. Children from the Greater Asunción area envenomed by T. trivittatus have presented psychomotor agitation, profuse sweat- ing, serum hypokalemia, and altered cardiac frequency as a result of left ventricular dysfunction (Borges \& Rojas de Arias, 2019). These are known consequences of the exacerbation of neurotransmitter release because of the action of low molecular mass scorpion venom neurotoxins either on voltage-sensitive sodium (NaTx) or potassium (KTx) channels expressed in excitable tissues. Some of these manifestations have also been observed in the case of envenomation by $T$. carrilloi n. sp. (de Roodt et al., 2003). Lethality of T. trivittatus venom (medium lethal dose, $\mathrm{LD}_{50}=1.19 \mathrm{mg}$ venom $/ \mathrm{kg}$ mice body weight) is within the same range of toxicity of other Tityus scorpion venoms in South America including $T$. carrilloi $\mathrm{n}$. sp. and T. serrulatus (Borges et al., 2020a). Comparative mass spectrometry of $T$. trivittatus and T. carrilloi n. sp. venoms have revealed the existence of shared as well as species-specific NaTxs, the components mainly associated with lethality of buthid scorpion venoms. In the NaTx mass range $(6-8 \mathrm{kDa})$, peptides unique to $T$. trivittatus were components 6726.6, 6916.5, and 7263.5 Da. Whereas peptides unique to T. carrilloi $\mathrm{n}$. sp. were $6630.0,6754.5$, 6787.5, 7047.9, 7324.1, and 7598.4 Da. Both species shared two components in this mass range, 6606.1 and $6941.1 \mathrm{Da}$, the latter corresponding to toxin Tt1g, isolated from T. carrilloi $\mathrm{n}$. sp. venom obtained from Entre Ríos, Argentina (Borges et al., 2020a). Tt1g is a NaTx acting on the activation component of voltage-gated sodium channels and specifically modifies sodium channel subtypes Nav1.2 and Nav1.3 (Coronas et al., 2015). No components were shared in the mass range of KTxs and antimicrobial peptides (2-5 $\mathrm{kDa}$ ). Some degree of commonality in the physiopathology of envenomation by both species is expected because of shared NaTxs, and also hyaluronidases and metalloproteases (Borges et al., 2020b). However, it cannot be discarded at present that differences may exist in venom function between $T$. trivittatus and T. carrilloi n. sp. considering that phylogenetically related NaTxs with distinct surface chemistry differentially promote release of neurotransmitters and recognize tissue-specific voltage-gated sodium channel subtypes (Vasconcelos et al., 2005; Borges \& Graham, 2016). Species-specific proteases in T. carrilloi n. sp. and T. trivittatus have also been uncovered by in-gel digestion and mass spectrometry procedures (Borges et al., 2020a). Additionally, the fact that no KTxs are shared between T. trivittatus and T. carrilloi $\mathrm{n}$. sp. is also indicative of potential physiopathological differ- 
ences considering that KTxs are among the most expressed toxins in venom glands of buthid scorpions and that potassium channels are the most diverse pharmacological targets of scorpion venoms from a functional standpoint (Kuzmenkov et al., 2015).

Preliminary in vivo neutralization assays using anti-T. carrilloi $\mathrm{n}$. sp. and anti-T. serrulatus antivenoms suggest that $T$. trivittatus venom is differentially recognized by these antibodies (Borges et al., 2020b). The anti-T. carrilloi n. sp. antivenom in partial experiments, using 3 LD50 of T. trivittatus venom preincubated with $100 \mathrm{ul}$ of antivenom, protected half of the mice challenged ( 2 survivors over 4 tested) as opposed to incubation with anti-T. serrulatus antivenom (4 surviving over 4 challenged). This suggests that $T$. trivittatus venom is differentially recognized by these antibodies (Borges et al., 2020b). Additionally, competitive enzyme-linked immunosorbent assays indicated that $T$. trivittatus and T. carrilloi $\mathrm{n}$. sp. venoms differ in their binding to Argentinean antivenom antibodies (Borges et $a l ., 2020 \mathrm{~b})$. Further experiments are required to determine the true neutralization efficiency of these antivenoms in the case of T. trivittatus, and the basis for the possible immunological differences among T. trivittatus, T. serrulatus, and T. carrilloi n. sp. venoms. Experimental results obtained in neutralization assays performed with therapeutic anti-scorpion antivenoms should be carefully interpreted due to the differences in pharmacological presentations of the available products (de Roodt et al., 2014). These differences could influence the results of the immunological studies, not due to immunological reasons, but pharmacological, related with potency required by pharmacopeias, and protein content, among other factors. As the scorpionism problem in Paraguay is emerging, research is currently being carried out to determine the extent of the venom relationships between $T$. trivittatus and its synanthropic Argentinean and Brazilian congeners.

\section{ACKNOWLEDGMENTS}

FSC thanks Lita Castañeda Betancur for her help in the molecular laboratory. Part of this work was supported by a grant from CONACYTMéxico, Ciencia Básica project number A1-S15134 to FSC. AB is thankful to CONACYTParaguay for financial support (project PRID1812). DGO \& AAOA are thankful to the director of the National Museum of Natural History of
Paraguay Luis Moran for giving us his support. DGO is thankful to M. Sánchez, J. Movia and N. Cantero, for helping in the capture of specimens. AAOA is thankful to CONICET-Argentina for financial support (projects PIP 2015-0672 \& PUE 2016-0098), to Lucas Damer who provided the type material of Tityus carrilloi n. sp., to Nadine Dupérré and Danilo Harms for their help with the photos of the type material of Tityus trivittatus, to Abel Pérez González for his help in our collection trip to Paraguay, and particularly to Family Guerrero-Orellana for their hospitality. We are also indebted to Leonardo Carvalho, and an anonymous reviewer, as well as to the editor Luciano Patitucci for their comments on an earlier version of the MS.

\section{REFERENCES}

Ábalos, J.W. 1959. Scorpionida. Primeras Jornadas Entomoepidemiológicas Argentinas. Quinta Sesión Científica (Buenos Aires): 591-593.

Ábalos, J.W. 1963. Scorpions of Argentina. In: H.L. Keegan \& W.V. Macfarlane (eds.), Venomous and poisonous animals and noxious plants of the Pacific region, pp. 111-117, New York, McMillan..

Abdel-Mottaleb, Y., F.V. Coronas, A.R. de Roodt, L.D. Possani \& J. Tytgat. 2006. A novel toxin from the venom of the scorpion Tityus trivittatus, is the first member of a new $\alpha$-KTX subfamily. FEBS Letters 580(2): 592-596. DOI: 10.1016/j.febslet.2005.12.073.

Acosta, L.E. 1991. Escorpiones y opiliones de la Provincia de Córdoba (Argentina): diversidad y zoogeografía. Bulletin de la Société Neuchâteloise des Sciences Naturelles. Comptes Rendus du XIIème Colloque Européen d'Arachnologie (Paris, 2-4 Juillet 1990) 116(1): 11-17.

Acosta, L.E. 1995. The scorpions of the Argentinian western Chaco. I. Diversity and distributional patterns. Biogeographica 71(2): 49-59.

Acosta, L.E. \& B. Rosso De Ferradás. 1996. Arácnidos de la Provincia de Córdoba. In: I. E. Di Tada, \& E. H. Bucher (eds.), Biodiversidad de la Provincia de Córdoba, Fauna. pp. 71-99, Universidad de Río Cuarto.

Acosta, L.E. \& E.A. Maury. 1998. Scorpiones. In: J. J. Morrone \& S. Coscarón (eds.), Biodiversidad de Artrópodos Argentinos, pp. 545-559, Ediciones Sur, La Plata, Argentina.

Adilardi, R.S., A.A. Ojanguren-Affilastro, D.A. Martí \& L.M. Mola. 2014. Cytogenetic analysis on geographically distant parthenogenetic populations of Tityus trivittatus Kraepelin 1898 (Scorpiones, Buthidae): karyotype, constitutive heterochromatin and rDNA localization. Comparative Cytogenetics 8: 81-92. doi: 10.3897/CompCytogen. v8i2.6461

Adilardi, R.S., A.A. Ojanguren-Affilastro, C.I. Mattoni \& L.M. Mola. 2015. Male and female meiosis in 
the mountain scorpion Zabius fuscus (Scorpiones, Buthidae): heterochromatin, rDNA and TTAGG telomeric repeats. Genetica 143(4): 393-401. doi: 10.1007/s10709-015-9838-1 PMID: 25899730.

Blanco, G., R.D. Laskowicz, L.C. Lanari, E. Scarlato, C.F. Damin, E. de Titto \& A.R. de Roodt. 2016. Distribution of findings of scorpions in Buenos Aires city in the period 2001-2012 and their sanitary implications. Archivos Argentinos de Pediatría 114(1): 77-83 / 77. doi: 10.5546/aap.2016.77.

Borelli, A. 1899. Viaggio del Dott. A. Borelli nella Republica Argentina e nel Paraguay. XXIII. Scorpioni. Bollettino dei musei di zoologia ed anatomia comparata della $R$. Università di Torino 14 (336): 1-6.

Borelli, A. 1901. Scorpioni raccolti dal Dott. Filippo Silvestri nella Republica Argentina e regioni vicine. Bollettino dei musei di zoologia ed anatomia comparata della $R$. Università di Torino, 17(422): $1-3$.

Borges, A. \& M.R. Graham. 2016. Phylogenetics of Scorpions of Medical Importance. In: P. Gopalakrishnakone \& J.J. Calvete (eds.), Venom Genomics and Proteomics, pp. 81-104, (). Heidelberg, Springer Dordrecht..

Borges, A. \& A. Rojas de Arias. 2019. El Accidente por Escorpiones Tóxicos en el Paraguay: Mito y Realidad en el contexto de la Emergencia por Escorpionismo en el Sudeste de la América del Sur. Revista de la Sociedad Científica de Paraguay 24(1): 27-35.

Borges, A, A. Rojas de Arias, S. de Almeida-Lima, B. Lomonte, C. Díaz, C. Chávez-Olórtegui, M.R. Graham, E. Kalapothakis, C. Coronel \& A.R. de Roodt. 2020a. Genetic and toxinological divergence among populations of Tityus trivittatus Kraepelin, 1898 (Scorpiones: Buthidae) inhabiting Paraguay and Argentina. PLOS Neglected Tropical Diseases, 14(12): e0008899. https://doi.org/10.1371/journal. pntd.0008899.

Borges, A., B. Lomonte, Y. Angulo, H. Acosta de Patiño, J.M. Pascale, R. Otero, R.J. Miranda, L. De Sousa, M.R. Graham, A. Gómez, P. Pardali, E. Ishikawa, F. Bonilla, A. Castillo, R.A. Machado de Avila, P.J. Gómez \& J.A. Caro-López. 2020b. Venom diversity in the Neotropical scorpion genus Tityus: Implications for antivenom design emerging from molecular and immunochemical analyses across endemic areas of scorpionism. Acta Tropica 204 (2020) 105346.

Bücherl, W. 1959. Escorpiões e escorpionismo no Brasil, $\mathrm{X}$. Cátalogo de coleção escorpionica do Instituto Butantan. Memorias do Instituto Butantan 29: 255-275.

Bücherl, W. 1964. Distribução geográfica dos Aracnóides peçoentos temíveis. Memorias do Instituto Butantan 31: 55-66.

Bücherl, W. 1969. Giftige Arthropoden. In: E.J. Fittkau, J. Illies, H. Klinge, \& Schwabe, G.H. (eds.), Biogeography and Ecology in South America (Monographiae Biologicae) (19), pp. 764-793, Dordrecht. W. Junk 2.
Bücherl, W. 1971. Calssification, biology and venom extraction of scorpions. In: W. Bücherl \& E. Buckley (eds.), Venomous animals and their venoms 3, pp. 317-348, New York, Academic Press.

Bücherl, W. 1978. Venoms of Tityinae. A. Systematics, distribution, biology, venomous aparatus, etc. of Tityinae; venom collection, toxicity, human accidents and treatment of stings. In: S. Bettini (ed.), Arthropod venoms, Handbook of experimental pharmacology, 48, pp. 371-379, Springer Verlag, Berlin,

Camargo, F.J. \& I.A. Ricciardi. 2000. Sobre la presencia de un escorpión Tityus serrulatus Lutz y Mello (Scorpiones, Buthidae) en la ciudad de Corrientes. Universidad Nacional del Nordeste, Comunicaciones Científicas y Tecnológicas. 3 pp.

Carvalho, L., A. Brescovit, C. Souza \& J. Raizer. 2017. Checklist dos escorpiões (Arachnida, Scorpiones) do Mato Grosso do Sul, Brasil. Iheringia, Série Zool 107(supl.): e2017108.

Ceccarelli, F.S., A.A. Ojanguren-Affilastro, M.J. Ramirez, J.A. Ochoa, C.I. Mattoni \& L. Prendini. 2016 Andean uplift drives diversification of the bothriurid scorpion genus Brachistosternus. Journal of Biogeography 43: 1942-1954.

Coronas, F.E., A.R. de Roodt, L. Olamendi-Portugal, F.Z. Zamudio, C.B. Batista, F. Gómez- Lagunas \& L. Posani. 2003. Disulfide bridges and blockage of Shaker B K+ - channels by another butantoxin peptide purified from the Argentinean scorpion Tityus trivittatus. Toxicon 41(2): 173-179.

Coronas, F.I.V., E. Diego-García, R. Restano-Cassulini, A.R. de Roodt \& L. Possani. 2015. Biochemical and physiological characterization of a novel $\mathrm{Na}^{+}$channel specific peptide from the venom of the Argentinean scorpion Tityus trivittatus. Peptides 68: 11-16. pii: S0196-9781(14)00148-X. doi: 10.1016/j.peptides.2014.05.002.

de Roodt, A.R. 2014. Comments on Environmental and Sanitary Aspects of the Scorpionism by Tityus trivittatus in Buenos Aires City, Argentina. Toxins (Basel) 6: 1434-1452.

de Roodt, A.R. 2015. Veneno de escorpiones (alacranes) y envenenamiento. Acta Bioquímica Clínica Latinoamericana. Revisión 49(1): 55-71.

de Roodt, A.R., E. Gimeno, E. Portiansky, L. Varni, J.A. Dolab, L. Segre, S. Litwin \& J.C. Vidal. 2001. A study on the experimental envenomation in mice with the venom of Tityus trivitattus Kraepelin 1898 (Scorpiones, Buthidae) captured in Argentina. Journal of Natural Toxins 10(2): 99-109.

de Roodt, A.R., S.I. García, O.D. Salomón, L. Segre, J.A. Dolab, R.F. Funes \& E.H. de Titto. 2003. Epidemiological and clinical aspects of scorpionism by Tityus trivittatus in Argentina. Toxicon 41(8): 971-977.

de Roodt, A.R., N.R. Lago, O.D. Salomón, R.D. Laskowicz, L.E. Neder de Román, R.A. López, T.E. Montero \& V. del Vega. 2009. A new venomous scorpion responsible for severe envenomation in Argentina: Tityus confluens. Toxicon 53(1): 1-8. de Roodt, A.R., F.I.V. Coronas, N. Lago, M.E. González, 
R.D. Laskowicz, J.C. Beltramino, S. Saavedra, R.A. López, G. Reati, M.G. Vucharchuc, E. Bazán, L. Varni, O.D. Salomon \& L. Possani. 2010. General, biochemical and immunological characterization of the venom from the scorpion Tityus trivittatus of Argentina. Toxicon 55(2-3): 307-319.

de Roodt, A.R., L.C. Lanari, R.D. Laskowicz \& V. Costa de Oliveira. 2014. Identificación de los escorpiones de importancia médica en la Argentina. Acta Toxicológica Argentina 22(1): 5-14.

de Roodt, A.R., L.C. Lanari, N. Casas, S.I García, V. Costa de Oliveira, C.F. Damin \& E.H. de Titto. 2017. Accidentes y muertes por animales venenosos en Argentina durante el período 2000-2011. Revista Ecuatoriana de Ciencias Tecnología e Innovacion en Salud Pública 1(1): 1-24. http://www.inspilip. gob.ec/wp-content/uploads/2017/07/19-Mortalidad-2000-2011-25.pdf.

de Roodt, A.R., L.C. Lanari, R.D. Laskowicz, V. Costa de Oliveira, S. Litwin, L. Calderon, C.F. Damin, J.C. Dokmetjian, J.A. Dolab, N.R. Lago \& E. Lértora. 2019. Study on the obtaining of Tityus trivittatus venom in Argentina. Toxicon 159: 5-13.

Docampo, P.C. \& M.E. Fernández. 2011. Escorpionismo: presentación de un posible caso grave ocurrido en la Ciudad de Buenos Aires. Acta Toxicológica Argentina 19(1): 16-18.

Donato, M., P. Posadas, D.R. Miranda-Esquivel, E. Ortiz-Jaureguizar \& G. Caldera. 2003. Historical biogeography of the Andean region: evidence from Listroderina (Coleoptera: Curculionidae: Rhytirrhinini) in the context of the South American geobiotic scenario. Biological Journal of the Linnean Society 80: 339-352.

Drummond, A.J., M.A. Suchard, D. Xie \& A. Rambaut. 2012. Bayesian phylogenetics with BEAUti and the BEAST 1.7. Molecular Biology and Evolution 29: 1969-1973.

Faúndez, E. \& M. Albornoz. 2017. Sobre un registro de predación de Steatoda triangulosa (Walckenaer, 1802) (Araneae: Theridiidae) sobre Tityus trivittatus Kraepelin, 1898 (Scorpiones: Buthidae) en Argentina. Revista Ibérica de Aracnología 30: 165-166.

Fet, V., M.E. Soleglad \& G. Lowe. 2005. A new trichobothrial character for the high level systematics of Buthoidea (Scorpiones: Buthida). Euscorpius 23: $1-40$.

Fernández, M.L., S.C. Lloveras, C. Falcone, G. González, S. Garro, S. Echazarreta, O. Martino \& T.A. Orduna. 2018. Scorpion stings in Buenos Aires, Argentina: Epidemiological and clinical aspects. Acta Toxicoloógica Argentina 26(1): 12-18.

Fernández-Campón, F. \& S. Lagos Silnik. 2009. Primer registro de Tityus trivittatus (Scorpiones: Buthidae) en la provincia de Mendoza (Argentina). Revista de la Sociedad Entomológica Argentina 68(1-2): 219-221.

Guerrero, D. \& J.A. Kochalka. 2015. Nuevos registros y revisión de localidades de Buthidae (Arachnida: Scorpiones) para el Paraguay. Boletín del Museo Nacional de Historia Natural de Paraguay 19(2):
$62-6$.

Koch, C.L. 1836. Die Arachniden. Nürnberg: C. H. Zeh `sche Buchhandlung 3(1-5): 17-104.

Koch, C.L. 1837. Uebersicht des Arachnidensystems. Nürnberg: C. H. Zeh `sche Buchhandlung 1: 1-39.

Koch, C.L. 1850. Scorpionen. In Uebersicht des Arachnidensystems. Nürnberg: C. H. Zeh`sche Buchhandlung 5: 86-92.

Kovarik, F. 1992. Check list of Scorpions (Arachnida, Scorpiones) in the collections of the Zoological department, National Museum in Prague. Acta Societatis Zoologicae Bohemoslovacea 56: 1891186.

Kovarik, F. 1998. Stiri. (Scorpions). Madagaskar, Jihlava, 175 pp.

Kraepelin, K. 1898. Neue Pedipalpen und Skorpionen des Hamburger Museums. Mitteilungen aus dem Naturhistorischen Museum. Beiheft zum Jahrbruch der Hamburgischen Wissenschaftlichen Anstalten 15: 39-44.

Kraepelin, K. 1899. Scorpiones und Pedipalpi. In: R. Friedlander \& Sohn (eds.), Das Tierreich. 8 (Arachnoidea), pp. 1-265, Berlin, Deutschen Zoologischen Gesellschaft.

Kraepelin, K. 1901. Catalogue des scorpions des collections du Muséum d'histoire naturelle de Paris. Bulletin du Muséun National d'Histoire Naturelle, Paris 7: 265-273.

Kraepelin, K. 1908. Die sekundären Geschlechtscharaktere der Skorpione, Pedipalpen und Solifugen. Mitteilungen aus dem Naturhistorischen Museum. Beiheft zum Jahrburch der Hamburgischen Wissenschaftlichen Ansalten 25: 181-225.

Kuzmenkov, A.I., E.V. Grishin \& A.A. Vassilevski. 2015. Diversity of Potassium Channel Ligands: Focus on Scorpion Toxins. Biochemistry (Mosc) 80(13): 1764-99. doi: 10.1134/S0006297915130118.

López, C.A., E. Couto \& A. Gularte. 2019. Escorpionismo y primeros registros de Tityus trivittatus y Tityus serrulatus en Puerto Iguazú, provincia de Misiones. Revista Argentina de Salud Pública 10(40): 51-54.

Lourenço, W.R. 1979. La repartition géographique du complexe Tityus trivittatus (Scorpiones, Buthidae). Revista Nordestina de Biologia 2(1/2): 37-49.

Lourenço, W.R. 1980 Contribution à la connaissance sytématique des Scorpions appartenant au "complexe" Tityus trivittatus Kraepelin, 1898 (Buthidae). Bulletin du Muséun National d'Histoire Naturelle, Paris 4 (2): 793-843.

Lourenço, W.R. 1981. Sur la Systématique des Scorpions appartenant au "complexe" Tityus stigmurus (Thorell 1877) (Buthidae). Revista Brasileira de Biologia 41: 351-362.

Lourenço, W.R. 1982. Le veritable statut des forms du "complexe" Tityus trivittatus Kraepelin, 1898 (Scorpiones, Buthidae). Note complémentaire. Bollettino dei musei di zoologia ed anatomia comparata della $R$. Università di Torino 1: 1-4.

Lourenço, W.R. 1986. Les modeles de distribution geographique de quelques groupes de scorpions neotropicaux. Comptes Rendus des Scéances de la 
Société de Biogéographie 62: 61-83.

Lourenço, W.R. 1994. Synopsis de la faune des Scorpions (Chelicerata) du Paraguay. Revue Suisse de Zoologie 101(3): 677-684.

Lourenço, W.R. 1997. Additions a la faune de Scorpions Neotropicaux. Revue Suisse de Zoologie 104(3): 587-604.

Lourenço, W.R. 2001. Scorpions of Brazil. Les Editions de l'IF, Paris, 320 pp.

Lourenço, W.R. 2006. Nouvelle proposition de découpage sous-générique du genre Tityus C. L. Koch, 1836 (Scorpiones, Buthidae). Boletín de la Sociedad Entomológica Aragonesa 39: 55-67.

Lourenço, W.R. 2015. What do we know about some of the most conspicuous scorpion species of the genus Tityus? A historical approach. Journal of Venomous Animals and Toxins including Tropical Diseases 21: 20. doi:10.1186/s40409-015-0016-9.

Lourenço, W.R. \& E.A. Maury. 1985. Contribution a la connaissance Sytésmatique des scorpions appartenant au "complexe" Tityus bolivianus Kraepelin 1895 (Scorpiones, Buthidae). Revue Arachnologie 6: $107-126$.

Lutz, A. \& O. De Mello. 1922. Contribucão para o conhecimento dos escorpioes brasileiros. Fohla Medica, Anales 3(6): 25.

Martínez, P.A., M.A. Andrade \& C.J. Bidau. 2018. Potential effects of climate change on the risk of accidents with poisonous species of the genus Tityus (Scorpiones, Buthidae) in Argentina. Spatial and Spatio-temporal. Epidemiology 25: 62-72.

Maury, E.A. 1970. Redescripción y distribución en la Argentina de Tityus trivittatus trivittatus Kraepelin, 1898 (Scorpiones, Buthidae) comentarios sobre sus hábitos domiciliarios y su peligrosidad. Physis, Sec. C 29: 405-421.

Maury, E.A. 1974. Escorpiofauna chaqueña. II. Tityus confluens Borelli 1899 (Buthidae). Physis, Sec. C 33:85-92.

Maury, E.A. 1979. Apuntes para una zoogeografía de la escorpiofauna argentina. Acta Zoologica Lilloana 35: 703-719.

Maury, E.A. 1984. Lista de los escorpiones conocidos de Paraguay (Scorpiones, Buthidae, Bothriuridae). Neotropica 30(84): 215-217.

Maury, E.A. 1986. Guía para la identificación de los escorpiones de la provincia de Buenos Aires. Ed. del autor, Buenos Aires, 10 pp.

Maury. E.A. 1997. Tityus trivittatus en la Argentina: Nuevos datos sobre su distribución, partenogénesis, sinantropía y peligrosidad (Scorpiones, Buthidae). Publicaciones de extensión cultural y didáctica del Museo Argentino de Ciencias Naturales "Bernardino Rivadavia" 24: 1-24.

Mello-Campos, O. 1924a. Os escorpiões Brasileiros. Memorias do Instituto Oswaldo Cruz 17(2): 237301.

Mello-Campos, O. 1924b. Scorpions of Brazil. Memorias do Instituto Oswaldo Cruz 17(2): 303-363.

Mello-Leitão, C. de. 1931. Divisão e distribução do gênero Tityus Koch. Anais da Academia Brasileira de Ciências 3(3): 119-150.
Mello-Leitão, C. de. 1932. Notas sôbre escorpiões SulAmericanos. Archivos do Museo Nacional do Rio de Janeiro 34: 9-46.

Mello-Leitão, C. de. 1934. Estudo Monográfico dos Escopiões da Republica Argentina. Octava Reunión de la Sociedad Argentina de Patología Regional del Norte. Santiago del Estero 1933: 1-97.

Mello-Leitão, C. de. 1938. Notas sobre alacranes argentinos. Notas del Museo de La Plata. Zoolgía 3(9): 81-95.

Mello-Leitão, C. de. 1939a. Revisão do gênero Tityus. Physis 17: 57-76.

Mello-Leitão, C. de. 1939b. Les arachnides et la zoogéographie de l'Argentine. Physis, Sec. C 17: 601-630.

Mello-Leitão, C. de. 1945. Escorpiões Sul-Americanos. Archivos do Museo Nacional do Rio de Janeiro 40: 7-68.

Ministerio de Salud. 2011. Guía de prevención, diagnóstico, tratamiento y vigilancia epidemiológica del envenenamiento por escorpiones. ISBN 978-950-380107-9, 40 pp.

Ministerio de Salud Pública de la Provincia de Salta. Secretaria de Comunicación. 2011. Medidas de prevención contra la picadura de Alacranes.. [on line: 6 april 2019] http://www.salta.gov.ar/prensa/ noticias/medidas-de-prevencion-contra-la-picadura-de-alacranes/12882.

Murúa, F., L.E Acosta, J.C. Acosta \& C. Coria. 2002. Primeros registros de Tityus trivittatus Kraepelin (Scorpiones, Buthidae) en el oeste argentino. Multequina 11: 75-78.

Ochoa, J.A., R. Botero-Trujillo \& L. Prendini. 2010. On the troglomorphic scorpion Troglotayosicus humiculum (Scorpiones, Troglotayosicidae), with first description of the adults. American Museum Novitates 3691: 1-19. https://doi.org/10.1206/707.1.

Ojanguren-Affilastro, A.A. 2005. Estudio monográfico de los escorpiones de la República Argentina. Revista Ibérica de Aracnología 11: 75-241.

Ojanguren-Affilastro, A.A., C.I. Mattoni, J.A. Ochoa, M.J. Ramírez, F.S. Cecarelli \& L. Prendini. 2015. Phylogeny, species delimitation and convergence in the South American bothriurid scorpion genus Brachistosternus Pocock 1893: integrating morphology, nuclear and mitochondrial DNAq. Molecular Phylogenetics and Evolution 94: 159170.

Ojanguren-Affilastro, A.A., R.S. Adilardi, C.I. Mattoni, M.J. Ramírez \& F.S. Ceccarelli. 2017a. Dated phylogenetic studies of the southernmost American buthids (Scorpiones; Buthidae). Molecular Phylogenetics and Evolution 110: 39-49.

Ojanguren-Affilastro, A.A., R.S. Adilardi, R. Cajade, M.J. Ramirez, F.S. Ceccarelli \& L.M. Mola. 2017b. Multiple approaches to understanding the taxonomic status of an enigmatic new scorpion species of the genus Tityus (Buthidae) from the biogeographic island of Paraje Tres Cerros (Argentina). PLoS ONE 12(7): e0181337. https:// doi.org/10.1371/journal.pone.0181337.

Ojanguren-Affilastro, A.A., C. Bizzotto, L.C. Lanari, M. Remes-Lenicov \& A.R. de Roodt. 2019. Presencia 
de Tityus confluens Borelli en la ciudad de Buenos Aires y expansión de la distribución de las especies de importancia médica de Tityus (Scorpiones; Buthidae) en la Argentina. Revista del Museo Argentino de Ciencias Naturales, n. s. 21(1): 101112.

Ojeda, M.A. \& L.E. Neder de Román. 2017. Escorpiones y escorpionismo en la provincia de Jujuy. Acta Toxicológica Argentina 25(1): 12-22.

Penther, A. 1913. Beitrag zur kenntnis Amerikanischer Skorpione. Annalen des Kaisserlich-Königlichen Naturhistorischen Hofmuseums in Wien 27: 239252.

Peretti, A.V. 1994. Comportamiento de relación madre-cría de Tityus trivittatus Kraepelin, 1898 (Scorpiones, Buthidae). Boletín de la Sociedad Biológica de Concepción 65: 9-21.

Possani, L.D., B. Becerril, M. Delepierre \& J. Tytgat. 1999. Scorpion toxins specific for $\mathrm{Na}+$-channels. European Journal of Biochemistry 264: 287-300.

Prendini, L. 2000. Phylogeny and classification of the superfamily Scorpionoidea Latreille 1802 (Chelicerata, Scorpiones): an exemplar approach. Cladistics 16: 1-78. https://doi. org $/ 10.1111 / j .1096-0031.2000 . t b 00348 . x$.

Ringuelet, R.A. 1953. Geonemia de los escorpiones en la Argentina y las divisiones zoogeográficas basadas en su distribución. Revista del Museo de La Plata (N. S.), Zoología 4: 277-284.

Ronquist, F., M. Teslenko, P. Van Der Mark, D.L. Ayres, A. Darling, S. Höhna, B. Larget, L. Liu, M.A. Suchard \& J.P. Huelsenbeck. 2012. MrBayes 3.2: efficient Bayesian phylogenetic inference and model choice across a large model space. Systematics Biology 61: 539-542.

Salomón, O.D. \& A.R. de Roodt. 2001. Escorpiones: denuncias espontáneas en dos centros de referencia en la ciudad de Buenos Aires, 1997-2000. Medicina 61(4): 391-396.

Saucedo, A.L., D. Flores-Solis, R.C. Rodríguez de la Vega, B. Ramírez-Cordero, R. Hernández-López, P. Cano-Sánchez, R. Noriega-Navarro, J. GarcíaValdés, F. Coronas-Valderrama, A.R. de Roodt, L.G. Brieba, L.D. Possani \& F. del Río-Portilla. 2012. New tricks of an old pattern: structural versatility of scorpion toxins with common cysteine spacing. Journal of Biological Chemistry 287(15): 1232112330. DOI: $10.1074 /$ jbc.M111.329607.

Seiter, M. 2012. Developmental stages and repro- ductive biology in Tityus confluens Borelli, 1899 and Tityus ocelote (Francke \& Stockwell, 1987) (Scorpiones,Buthidae). Revista Ibérica de Aracnología 21: 113-118.

Seiter, M. \& M. Stockmann. 2017. The life history of the parthenogenetic scorpion Lychas tricarinatus (Simon, 1884) from Odisha province, India and supplementary notes on Tityus trivittatus Kraepelin, 1898 (Scorpiones, Buthidae). Zoologischer Anzeiger 270 (2017): 155-165.

Simon, E. 1879. 3e Ordre.-Scorpiones. In Les Arachnides de France. VII. Contenant les ordres des Chernetes, Scorpiones et Opiliones pp. 79-115. Paris, Roret.

Toledo-Piza Jr, S. 1932. Considerações a rispeito da systematica general do gênero Tityus e do Tityus bahiensis en particular. Revista de Agricultura 7: 295-306.

Toscano-Gadea, C.A. 2004. Confirmation of parthenogenesis in Tityus trivittatus Kraepelin, 1898 (Scorpiones, Buthidae). Journal of Arachnology 32: 866-869.

Toscano-Gadea, C.A. 2012. Clave para la identificación de las especies de escorpiones de Uruguay. INNOTEC 7: 82-89.

Vachon, M. 1974. [1973] Étude des caractères utilisés pour classer les familles et les genres de scorpions (Arachnides). 1. La trichobothriotaxie en arachnologie. Sigles trichobothriaux et types de trichobothriotaxie chez les scorpions. Bulletin du Muséun National d'Histoire Naturelle, Paris 104: 857-958. Vasconcelos, F., V.L. Lanchote, L.M. Bendhack, J.R. Giglio, S.V. Sampaio \& E.C. Arantes. 2005. Effects of voltage-gated $\mathrm{Na}+$ channel toxins from Tityus serrulatus venom on rat arterial blood pressure and plasma catecholamines. Comparative Biochemistry and Physiology C 141: 85-92.

Weidner, H. 1959. Die Entomologichen Sammlungen des Zoologischen Staatsintituts und Zoologischen Museums Hamburg. I. Teil. Pararthropoda und Chelicerata. I. Mitteilungen aus dem Hamburgischen Zoologischen Museum und Institut 57: 89-142.

Werner, F. 1902. Die Scorpione, Pedipalpen und Solifugen in der Zoologisch-vergleichendanatomischen Sammlung der Universitat Wien. Verhandlungen der Kaiserlich-Königlichen Zoologisch-Botanischen Gesellschaft in Wien 52: 595-608.

Doi: 10.22179/REVMACN.23.714

Recibido: 4-II-2021

Aceptado: 4-VI-2021 
